\title{
Molecular systematics of Haploginglymus, a genus of subterranean amphipods endemic to the Iberian Peninsula (Amphipoda: Niphargidae)
}

\author{
José A. Jurado-Rivera ${ }^{1,5}$, Genaro Álvarez², José A. Caro ${ }^{2,3}$, Carlos Juan ${ }^{1,4}$, Joan Pons ${ }^{4}$, Damià Jaume ${ }^{4}$ \\ ${ }^{1}$ Departament de Biologia, Universitat de les Illes Balears (UIB), Ctra. Valldemossa km 7’5, 07122-Palma de \\ Mallorca, Spain \\ ${ }^{2}$ Sociedad Espeleológica Geos (Exploraciones e Investigaciones Subterráneas), C/ Dr. Miguel Ríos Sarmiento 74, \\ 41020-Sevilla, Spain \\ ${ }^{3}$ Departamento de Geografía y Ciencias del Territorio, Universidad de Córdoba, Plaza del Cardenal Salazar 3, \\ 14071-Córdoba, Spain \\ ${ }^{4}$ IMEDEA (CSIC-UIB), Instituto Mediterráneo de Estudios Avanzados, C/ Miquel Marquès 21, 07190-Esporles, \\ Spain \\ ${ }^{5}$ E-mail: jose.jurado@uib.es
}

Key words: Stygofauna, Crustacea, taxonomy, cave fauna, phylogenetic relationships

\begin{abstract}
The molecular systematics of the subterranean amphipod genus Haploginglymus is addressed through the phylogenetic analysis of three DNA gene fragments (nuclear ribosomal $28 \mathrm{~S}$ and protein-coding Histone 3, plus mitochondrial Cytochrome c Oxidase subunit I). We take advantage of the description of a new species from southern Spain (Haploginglymus geos sp. nov.) to assess the singularity of this genus endemic to the Iberian Peninsula and the inclusion of the morphologically aberrant $H$. morenoi within Haploginglymus. Our results corroborate the monophyly of the family Niphargidae but shows Niphargus to be paraphyletic as it currently stands, with Haploginglymus appearing nested within it. A strongly supported sister-group relationship between niphargids and the (thalassoid) pseudoniphargids is recovered as well, but we propose the Niphargidae should continue to be considered as a primary limnic group for biogeographic purposes despite its presumed marine derivation. Our findings are in agreement with previous studies that suggest the family Niphargidae originated in the late Cretaceous in the NE Atlantic, from where it eventually expanded across continental Europe.
\end{abstract}

\section{Contents}

\begin{tabular}{|c|c|}
\hline Introduction ................... & 239 \\
\hline Material and methods & 240 \\
\hline Study site ...................... & \\
\hline Material examined …………………………………........ & \\
\hline DNA isolation, PCR amplification and sequencing & \\
\hline 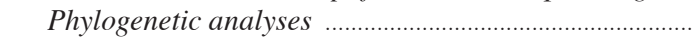 & \\
\hline Results & \\
\hline 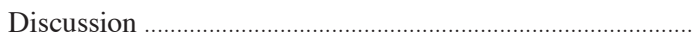 & \\
\hline 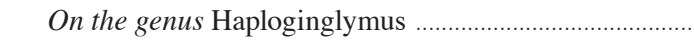 & \\
\hline Origin, intra-generic relationships and biogeography & \\
\hline 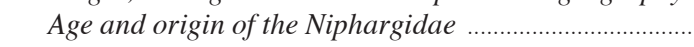 & \\
\hline 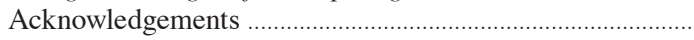 & \\
\hline
\end{tabular}

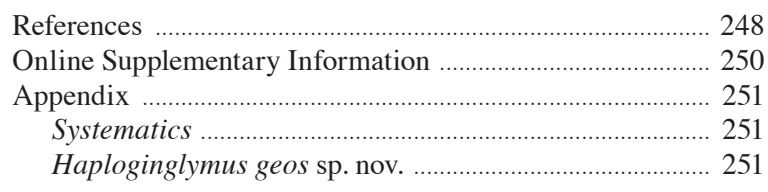

\section{Introduction}

Haploginglymus Mateus and Oliveira-Mateus, 1958, is a genus of niphargid amphipod endemic to the fresh inland subterranean waters of the Iberian Peninsula (Spain and Portugal). It is found in caves, wells and the interstitial medium associated to riverbanks, but apparently avoids the brackish waters of coastal aquifers. First discovered in wells from the lower course of river Douro in NW Portugal, the genus displays a broad distribution across the entire Peninsula, where it is one of the most common subterranean crustaceans (Notenboom, 1990). The genus was originally distinguished from Niphargus Schiödte, 1849 - by far the largest genus among freshwater amphipods (408 valid species; Lowry, 2010) - based on the display of an unsegmented (vs. 2-segmented) exopod on uropod III. Nevertheless, two additional niphargid genera described later on, both monotypic, viz. Carinurella Sket, 1971, and Niphargobates Sket, 1981, share with Haploginglymus the same condition of uropod III, although both can be readily told apart from Haploginglymus based on other features (Sket, 1971; 1981).

Despite its almost generalised distribution across Iberia, only five species of Haploginglymus have been 
formally described thus far (Mateus and OliveiraMateus, 1958; Stock, 1980; Karaman, 1986; Pretus and Sabater, 1990; Iannilli et al., 2009). Aside the morphologically aberrant $H$. morenoi Iannilli, Minelli and Ruffo, 2009, which displays a modified spatulate maxillipedal palp, slender gnathopods and strongly sexually-dimorphic gnathopod II, all show a rather uniform, ordinary Niphargus-like aspect. Anyway, molecular analyses under way suggest the genus mirrors the condition described elsewhere for Niphargus, where each species displays a very reduced distribution and the few presumed widespread species correspond in fact to complexes of stenochorous cryptic species (Trontelj et al., 2009; Meleg et al., 2013).

As a first step to explore the diversification of Haploginglymus in Iberia, we combine herein morphology and molecular traits to describe a new species from southern Spain. We use DNA sequences of three gene fragments (nuclear ribosomal 28S and protein-coding Histone 3, plus mitochondrial Cytochrome c Oxidase subunit I) to assess the distinctiveness of this Iberian genus in front of the rest of niphargids, and the placement of the morphologically aberrant $H$. morenoi within Haploginglymus. In addition, we have found the Pseudoniphargidae Karaman, 1993 to be the closest relative to niphargids, which gives a new perspective to the debate on the origin, diversification and biogeography of this extremely diversified family of continental water amphipods.

\section{Material and methods}

Study site

The new species is known only from phreatic waters found in two caves located at Cerro de Santiago, a Cambrian limestone outcrop within the municipality of Cazalla de la Sierra (Seville, southern Spain). The area is next to Riera de Benalija, a tributary brook to the Guadalquivir River that flows into El Pintado reservoir. The cave lakes are hydrographically connected to the reservoir so that their level follows the annual oscillation of the reservoir's water table. Specimens were found crawling in high numbers on the bottom of the cave lakes and were readily attracted by bait. Some specimens were observed venturing in open water, but most remained associated to the substratum. Direct observations did not suggest the species carried an interstitial life. Crustaceans found accompanying the new species at the time of sampling include Metahadzia uncispina Notenboom, 1988; Salentinella seviliensis Platvoet, 1987; Stenasellus escolai Magniez, 1977; Microcharon marinus Chappuis and Delamare, 1954; Megacyclops brachypus Kiefer, 1954; Diacyclops bicuspidatus odessanus (Shmankevich, 1875); Cypria ophtalmica (Jurine, 1820) and a not yet determined harpacticoid copepod. In addition, the bathynellid syncarid Hexabathynella sevillaensis Camacho, 2005, was recently described from the same caves (Camacho, 2005).

\section{Material examined}

Specimens were collected directly with a hand-held plankton net in the cave lakes and fixed in situ in $95 \%$ ethanol. Once in the laboratory, they were dissected in lactic acid under the stereomicroscope, and appendages figured with a Leica DM2500 microscope equipped with Nomarski differential interference contrast and a drawing tube. Body measurements were derived from the sum of the maximum dorsal dimensions of body somites and exclude telson length. Type material is deposited in the invertebrate collection of Naturalis Biodiversity Center, Leiden (RMNH). Abbreviations and nomenclature used in morphological descriptions are as follows: A1 (antennule); A2 (antenna); G1-G2 (gnathopods I and II, respectively); P3-P7 (pereiopods III to VII, respectively); and U1-U3 (uropods I to III, respectively).

\section{DNA isolation, PCR amplification and sequencing}

Genomic DNA was purified from 13 specimens corresponding to nine different Haploginglymus taxa, viz. the new species described herein, the aberrant $H$. morenoi, and seven not yet formally described species coming from several Iberian locations (v. Table $1 \&$ Fig. 1). In addition, sequences from 14 specimens of Niphargus from four different populations from the Iberian western edge of the Pyrenees (Basque Country), as well as eight specimens belonging to six different Pseudoniphargus species from the Iberian Peninsula, Portugal and the Canary Islands were also obtained and included in the dataset as potentially close outgroups. DNA extraction was performed using the DNeasy Tissue kit (Qiagen, West Sussex, UK) following the manufacturer's protocol. Elutions were done in $100 \mu \mathrm{L}$ volume and $1 \mu \mathrm{L}$ was used in PCR reactions. Three different molecular markers were selected for the study, namely: a partial sequence of the mitochondrial Cytochrome $\mathrm{c}$ Oxidase subunit 1 gene (cox1; primers LCO1490 and HCO2189; Folmer et al., 1994), a partial sequence of 
Table 1. Material included in molecular analyses.

Taxon Locality

Haploginglymus geos sp. nov.

Haploginglymus morenoi Iannilli, Minelli and Ruffo, 2009

Haploginglymus sp.

Haploginglymus sp.

Haploginglymus sp.

Haploginglymus sp.

Haploginglymus sp.

Haploginglymus sp. 1

Haploginglymus sp. 2

Niphargus sp. 1

Niphargus sp. 2

Niphargus sp. 3

Niphargus sp. 4

Pseudoniphargus branchiatus

Pseudoniphargus daviui

Pseudoniphargus gorbeanus

Pseudoniphargus portosancti

Pseudoniphargus sp.

Pseudoniphargus sp.
Cazalla de la Sierra (Seville; Spain): Cueva del Ocho

Nonaspe (Zaragoza; Spain): resurgence under bridge at River Matarranya

Zagrilla la Alta (Córdoba; Spain): Manantial de Zagrilla

Priego de Córdoba (Spain): well at C/ Noria 27

Córdoba City (Spain): Arab aqueduct at C/ Cardenal Portocarrero

Villaluenga del Rosario (Cádiz; Spain): El Pozo Blanco

Estremenho Massif (Portugal): Gruta da Contenda

Nonaspe (Zaragoza; Spain): resurgence under bridge at River Matarranya

Nonaspe (Zaragoza; Spain): resurgence under bridge at River Matarranya

Zugarramurdi (Navarra; Spain): Cueva de las Brujas

Ilarduia (Alava; Spain): Manantial de Porraipi

Axpe (Busturia; Vizcaya; Spain): Cueva de San Pedro

Andoain (Guipúzcoa; Spain): turbera (peatbog) de Usabeiartza

Complejo el Romeral (Antequera, Spain)

Font d'Enciola (Cabrera Island, Spain)

Artzegi'ko Koba (Alava, Spain)

Fonte do Tanque (Madeira, Portugal)

Cueva Udías (Cantabria, Spain)

Mina de los Llanetes (Gran Canaria, Spain)

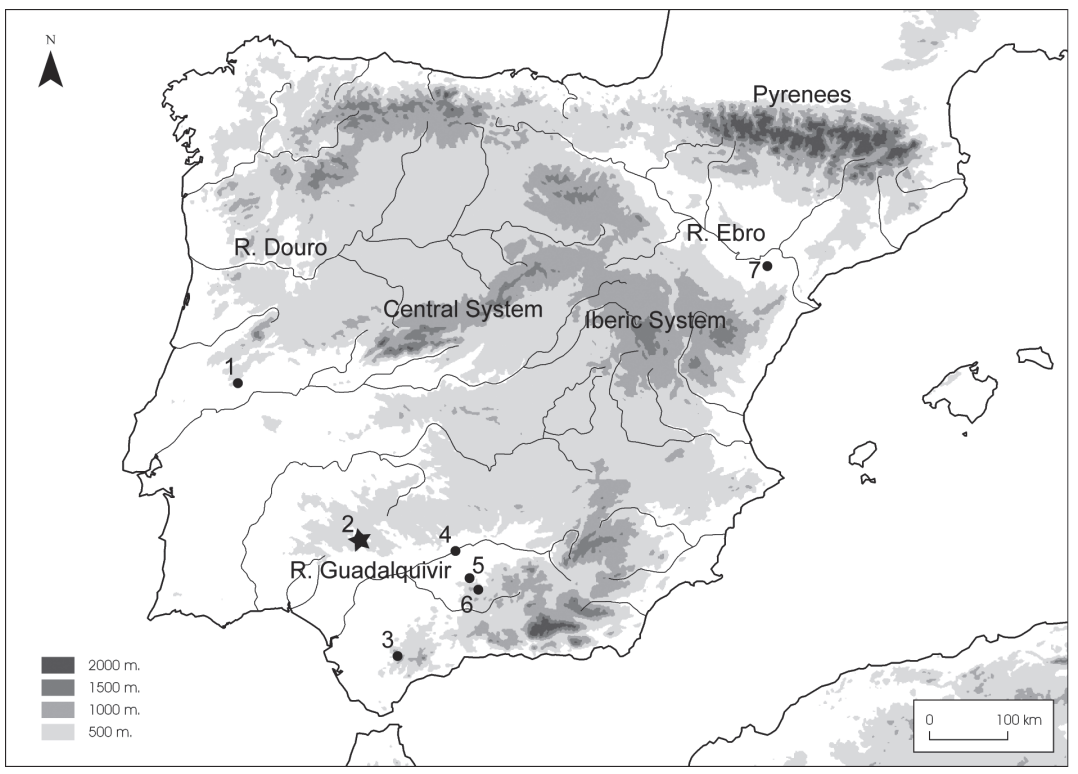

Fig. 1. Map of the Iberian Peninsula showing the location of the Haploginglymus samples included in the phylogenetic analysis. The type locality of the new Haploginglymus species described herein is marked with a star symbol. 1: Estremenho Massif; 2: Cerro de Santiago; 3: Villaluenga del Rosario; 4: Córdoba; 5: Zagrilla la Alta; 6: Priego de Córdoba; 7: Nonaspe. the nuclear ribosomal 28S ( $L S U$; primers $28 \mathrm{~S}$ lev2; Verovnik et al., 2005 Zakšek et al., 2007), and a fragment of the nuclear Histone 3 gene $(\mathrm{H} 3$; primers $\mathrm{H} 3 \mathrm{aF}$ and H3aR; Colgan et al., 1998). PCR conditions included $0.2 \mu \mathrm{M}$ of each primer and $3.5 \mathrm{mM} \mathrm{MgCl}_{2}$ using a standard protocol of 35 cycles, with annealing temperature ranging from 50 to $45^{\circ} \mathrm{C}(60 \mathrm{~s})$ depending on the sample. Denaturation $\left(94^{\circ} \mathrm{C}\right)$ and elongation $\left(72^{\circ} \mathrm{C}\right)$ lasted 30 and 60s, respectively. PCR products were inspected by electrophoresis in $1 \%$ agarose gel and purified using MSB Spin PCRapace (Invitek, Berlin, Germany). Sanger sequencing was performed with the same primers using the BigDye Terminator Cycle Sequencing kit (Applied Biosystems, Foster City, CA, USA). Sequences were edited and contigs were assembled using CodonCode Aligner (CodonCode Corporation, 
Dedham, MA, USA), and deposited at GenBank under the accession numbers referred in Table S1.

\section{Phylogenetic analyses}

The molecular dataset was complemented with sequences retrieved from GenBank corresponding to a selection of 134 Niphargus species/populations covering the entire geographical distribution and morphological disparity of the genus, plus four of the nine additional recognized niphargid genera ( $v$. Horton and Lowry, 2013), viz. Carinurella Sket, 1971, Pontoniphargus Dancău, 1968, Niphargobates Sket, 1981 and Niphargellus Schellenberg, 1938. We completed the dataset with a series of more distant outgroups in the families Gammaridae (6 genera), Gammaracanthidae (1), Eulimnogammaridae (1), Acanthogammaridae (1), Pallaseidae (1), Pontogammaridae (1), Anisogammaridae (1) and Crangonyctidae (3). We rooted the tree with a phoxocephalid and an urothoid, in accord with the most recent hypothesis on amphipod supra-familylevel relationships (Lowry and Myers, 2013). Data on all sequences and taxa used are shown in Table S1.

Multiple sequence alignment was performed using MAFFT 7 online version (http://mafft.cbrc.jp/alignment/ server/; Katoh and Standley, 2013), using the default FFT-NS-1 algorithm for the cox 1 and H3 datasets, and the Q-INS-i option for the LSU sequences since it considers the secondary structure of the RNA sequences. In order to evaluate the effect on the topology of the indels in the LSU alignment, an additional LSU matrix was generated by removing ambiguously aligned regions with Gblocks v. 0.91b (Talavera and Castresana, 2007), and specifying a minimum length of two positions for a block and selecting only positions with a gap in less than $50 \%$ of the sequences if they are within an appropriate block. Nucleotide substitution saturation was assessed with the Xia's test (Xia et al., 2003) implemented in DAMBE v. 5.2.64 (Xia, 2013). Since evidence of substitution saturation was detected on third coding positions of the cox 1 alignment (see Results), we also performed the phylogenetic analyses by excluding these characters from the dataset. Genetic divergence among Haploginglymus taxa was estimated through the calculation of the uncorrected pairwise cox1 distances (p-distance) in MEGA7 (Kumar et al., 2016). In order to test the phylogenetic congruence among the three molecular markers, single-gene trees were inferred and the resulting topologies were compared. Optimal partitioning strategy and evolutionary models for each alignment were assessed with Parti-
tionFinder (Lanfear et al., 2012) under the Bayesian Information Criterion (BIC), whereas the phylogenetic inference was conducted using IQTREE multicore v. 1.3.12 (Nguyen et al., 2015) performing 1000 ultrafast bootstrap approximation replicates. Finally, a phylogenetic analysis of the three molecular markers combined was independently carried out under both a maximum likelihood and a Bayesian framework using IQTREE and MrBayes 3.2 (Ronquist et al., 2012), respectively. For the latter, two independent analyses consisting of four chains each were run for $5 \cdot 10^{7}$ generations specifying a sampling frequency every 1000 generations, and setting up a burn-in fraction of 35\%. MCMC convergence and effective sample size (ESS) estimates were checked with TRACER v. 1.6 (Rambaut et al., 2013).

\section{Results}

Sequence statistics of the for the studied DNA datasets and their best partitioning and model selection schemes are shown in Tables 2 and 3, respectively. The topologies derived from the analyses performed both separately on each individual marker (Figs S2-S4) and on their concatenation (Figs 2; 3; v. Figs S5 \& S6 for a more detailed version of these trees) were consistent in showing the same evolutionary relationship between Haploginglymus and the rest of niphargid taxa. In all cases, all members of Haploginglymus were recovered as a monophyletic lineage nested within a clade that also included Niphargus, Pontoniphargus, Carinurella and Niphargobates. In turn, this paraphyletic clade appeared as sister to the members of the family Pseudoniphargidae. Although Xia's test showed low levels of substitution saturation except for third coding positions of the cox 1 alignment (ISS $=1.01$, ISSc $=0.689$, P twotailed $<0.00001$ ), the exclusion of the latter from the alignment did not affect the above-mentioned phylogenetic relationships, although nodal support was generally lower (Fig S7), suggesting third positions contributed phylogenetic signal rather than noise. Seemingly, the exclusion of ambiguous positions in the LSU alignment $(58 \%$ of the alignment positions were removed using Gblocks) did not affect the relationships among the main lineages (Fig S8).

As regard the main phylogenetic relationships among the nine Haploginglymus samples (Figs 2; 3; node A), two main lineages could be established. One of them (node B) corresponded to the three species from North Iberia, while the other clade (node $\mathrm{C}$ ) embraced the species from the southern half of the Peninsula. The 
latter includes three monophyletic lineages corresponding to the Portuguese taxon (node D), the new species from Cazalla de la Sierra described herein (see Appendix section; Node E), and the three species collected at the Subbaetic System (node F), respectively. The genetic divergence among Haploginglymus lineages - measured as uncorrected pairwise cox $1 \mathrm{p}$-distance is shown in Table 4.

\section{Discussion}

On the genus Haploginglymus

Our phylogenetic analysis corroborates the monophyly of the family Niphargidae but shows Niphargus to be paraphyletic as it currently stands (Figs 2; 3). The paraphyly of Niphargus was already suggested by Sket (1981) and implicitly recognized by Cene Fišer and coworkers, who in different molecular phylogenetic papers (Fišer et al., 2008; Hekmatara et al., 2013; Švara et al., 2015; Esmaeili-Rineh et al., 2015; Brad et al., 2015) showed Carinurella, Pontoniphargus, Niphargobates and Niphargellus nested within that genus. In our analysis, Haploginglymus appears also nested within Niphargus conforming a robustly supported monophyletic group. This clade is sister to another one conformed by the English Niphargellus glenniei (Spooner, 1952) and the Irish Niphargus irlandicus Schellenberg, 1932. These two taxa were already recovered as the most basal niphargids in the analyses performed by McInerney et al. (2014) and Brad et al. (2015). The retention of Haploginglymus as a valid genus in this context is thus implausible, especially taking into consideration that its presumed more remarkable diagnostic trait (the unsegmented U3 exopod) is shared also by the monotypic genera Niphargobates and Carinurella. Nevertheless, the former two genera differ remarkably from Haploginglymus in many relevant features, in accord with their peculiar life-styles.

In any event, our analysis recovers all Haploginglymus species conforming a clade geographically restricted to the Iberian Peninsula, where it replaces the rest of niphargids except for two small disjunct areas on both edges of the Pyrenees (Notenboom, 1990). As in Niphargus s.l., this monophylum includes some morphologically aberrant members such as $H$. morenoi that, if it were not because it displays an unsegmented U3, it would deserve that a new genus was erected to accommodate it. The potential for morphological disparity in Haploginglymus is thus as high as in Niphar- gus s. l., and would suggest a long, separate evolutionary history between both lineages, enabling Haploginglymus to colonise and adapt to even the most demanding subterranean niches in Iberia. Considering all these pieces of evidence and that Niphargus already accounts with more than 400 valid species, we opt here for the retention of Haploginglymus as a valid genus. As regard Haploginglymus morenoi and its aberrant morphology, our results fully agree with Iannilli et al. (2009) in considering it as a highly modified member of the genus with a peculiar, interstitial lifestyle.

\section{Origin, intra-generic relationships and biogeography}

Haploginglymus is endemic to the Iberian Peninsula, where it displays an almost generalised distribution in fresh subterranean waters and is the only niphargid known unless for two disjunct areas on both edges of the Pyrenees, where Niphargus also occurs (Notenboom, 1990). In those areas, the orography is less pronounced than at the central Pyrenean sector, to the point of enabling the local trans-Pyrenean colonization by Niphargus. The latter genus is broadly distributed across the rest of Europe and the Middle East (EsmaeiliRineh et al., 2015), and seems to have colonised the two foregoing Spanish regions quite recently, apparently after the establishment of Haploginglymus in Iberia. Thus, at least three of the four Niphargus species recorded in Catalonia display a trans-Pyrenean distribution (Karaman, 2015a; b), whereas those from the Basque Country conform a derived monophyletic group within the niphargid tree that appears to be unrelated to Haploginglymus (v. Fig. 2). Thus, the rise of the Pyrenees with its current structural organisation already at the Paleocene/Eocene boundary, 55-47 Myr ago (Vergés et al., 2002) might have played a major role in the differentiation of Haploginglymus from the rest of niphargids, with this age representing a terminus post quem for its origin (Fig. 1).

The nine Haploginglymus samples included in our analysis conform two main monophyletic groups (Figs 2; 3; nodes B and C). One (node B) appears associated to the River Ebro and its tributaries, and comprises the three species recorded at River Matarranya, of which only $H$. morenoi has been formally described thus far. The second group (node C) is distributed across the southern half of the Iberian Peninsula and comprises the rest of taxa. The genetic divergence among these Haploginglymus lineages is high, as deduced from the observed values of uncorrected pairwise cox 1 p-distances (Table 4). With the caveat that DNA sequences 

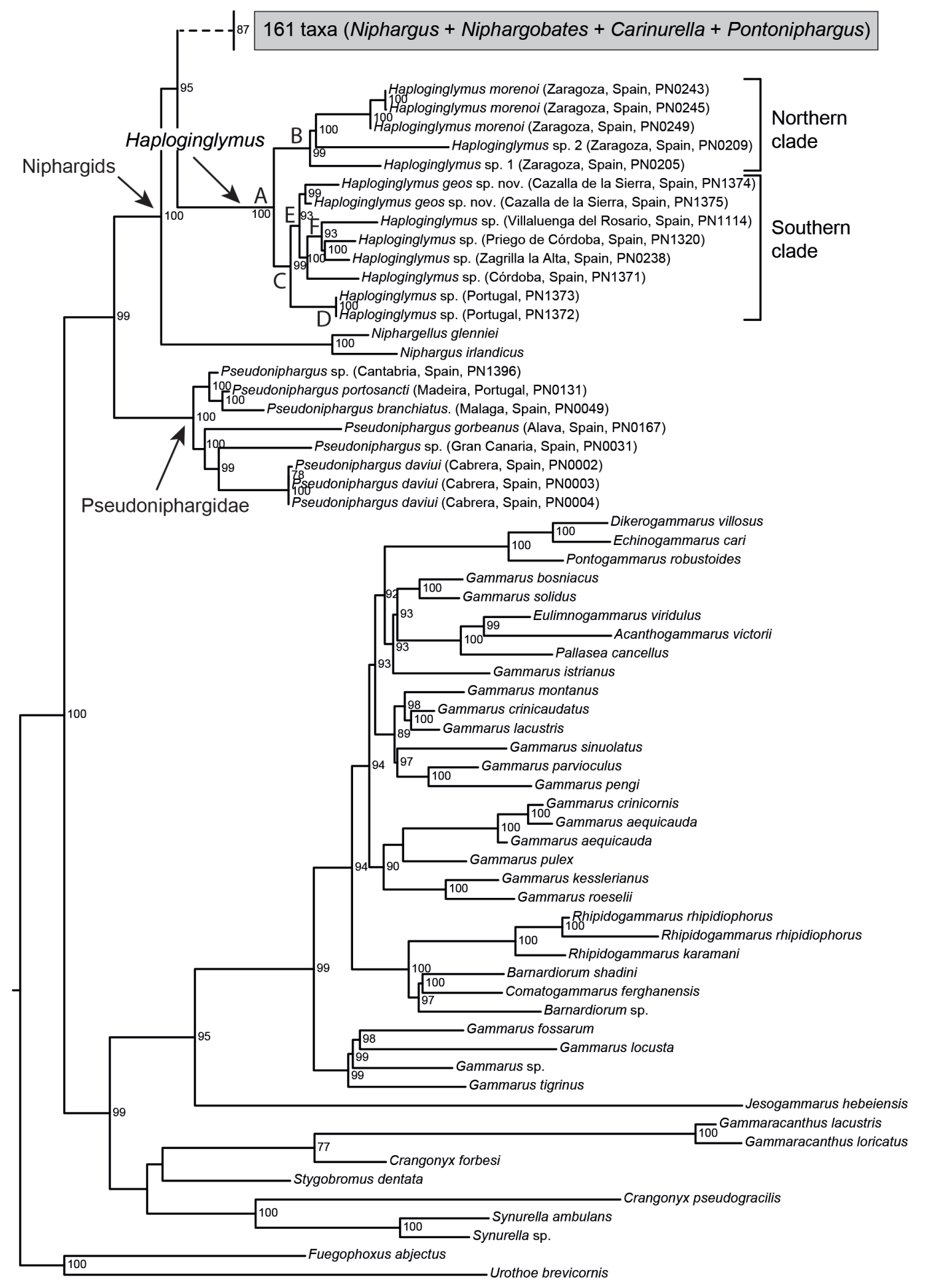

0.2

Fig. 2. Maximum likelihood phylogenetic tree based on the combined analysis of cox1, H3 and LSU. Node numbers represent statistical bootstrap support (only values $\geq 70$ are shown). Nodes in the Haploginglymus clade have been labelled for discussion in the text. See Supplementary Figure S5 for a more detailed version of this tree. 


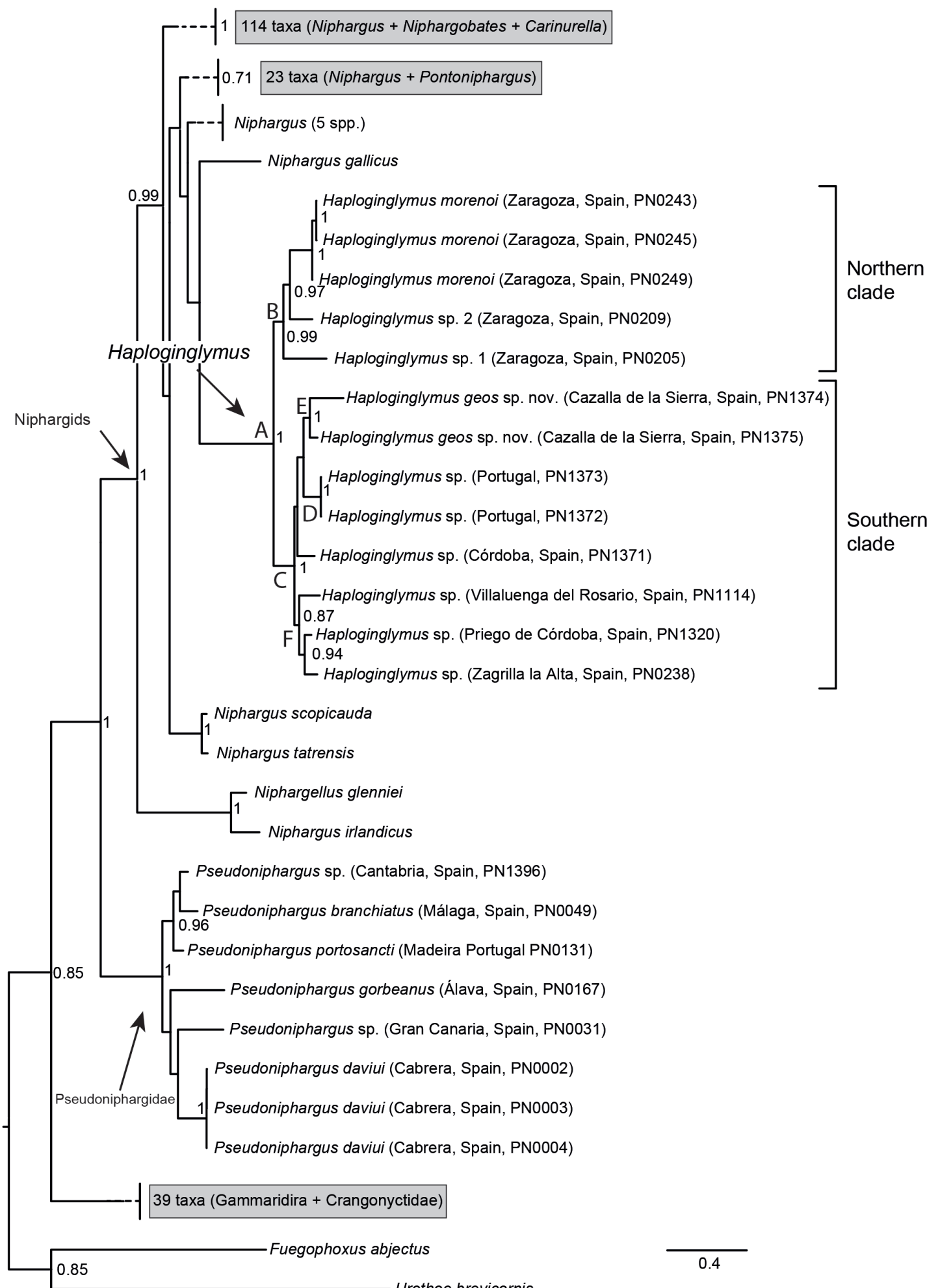

Fig. 3. Bayesian phylogenetic tree based on the combined analysis of cox1, H3 and LSU. Node numbers represent posterior probabilities (only values $\geq 0.70$ are shown). Nodes in the Haploginglymus clade have been labelled for discussion in the text. See Supplementary Figure S6 for a more detailed version of this tree. 
Table 2. DNA datasets sequence statistics (cod. pos. = coding position; seq = sequence; $\mathrm{bp}=$ base pairs; stdev. = standard deviation).

\begin{tabular}{|c|c|c|c|c|c|}
\hline Dataset & N. of seqs. & $\begin{array}{l}\text { Seq. length (bp) } \\
\text { (mean, stdev.) }\end{array}$ & $\begin{array}{l}\text { Alignment } \\
\text { length (bp) }\end{array}$ & $\begin{array}{l}\text { Informative } \\
\text { positions }(\%)\end{array}$ & $\mathrm{A}+\mathrm{T}(\%)$ \\
\hline $\operatorname{cox} 1$ & 170 & $155-621(572.4,95.7)$ & 621 & 53.3 & 64.3 \\
\hline $\operatorname{cox} 1$ (no cod. pos. 3 ) & 170 & $104-414(381.7,63.7)$ & 414 & 30.2 & 56.5 \\
\hline LSU & 191 & $436-921(816.9,89.8)$ & 1721 & 43.9 & 42.8 \\
\hline LSU (reduced with Gblocks) & 191 & $359-724$ & 724 & 60.5 & 42.1 \\
\hline $\mathrm{H} 3$ & 143 & $209-330(323.4,21.1)$ & 330 & 31.5 & 42.8 \\
\hline Combined & 210 & - & 2672 & 44.57 & 49.8 \\
\hline Combined (no cox 1 cod. pos. 3 ) & 210 & - & 2465 & 39.96 & 46.1 \\
\hline
\end{tabular}

Table 3. Results of partition and model selection analyses carried out in PartitionFinder (cod. pos. = coding position).

\begin{tabular}{llll}
\hline Dataset & Number of subsets & Partitioning schemme & Substitution model \\
\hline $\operatorname{cox} 1$ & 1 & unpartitioned & GTR+I+G \\
$\operatorname{cox} 1$ (excluding cod. pos. 3) & 1 & unpartitioned & SYM+I+G \\
LSU & 1 & unpartitioned & GTR+I+G \\
LSU (reduced with Gblocks) & 1 & unpartitioned & GTR+I+G \\
H3 & 1 & unpartitioned & K80+I+G \\
Combined & 2 & LSU+H3+cox1 cod. pos. 1+cox1 cod. pos. 2 GTR+I+G & GTR+I+G \\
Combined (excluding cox1 cod. pos. 3) & 1 & cox1 cod. pos. 3 & GTR+I+G \\
\hline
\end{tabular}

from representatives of other parts of the northern sector of the Peninsula are lacking, it is feasible to relate this primary subdivision of the genus to the uplift during the Tertiary Alpine orogeny of two intra-Peninsular mountain ranges: The Central System (that separates the Duero and Tajo river basins) and the Iberian System (that separates the Ebro river basin from the rest of the Peninsula) (v. Fig. 1).

\section{Age and origin of the Niphargidae}

Niphargids are almost completely bound to subterranean waters except for a few species recorded from surface habitats or the bottom of deep lakes (Karaman and Ruffo, 1986). The family occurs only in the Palaearctic west of the Caspian Sea and currently comprises ten valid genera, of which Niphargus, with 408 species, is by far the most species-rich. The rest embraces only 16 species (Horton and Lowry, 2013). Only Haploginglymus is allopatric with respect to the rest of niphargids, although it overlaps with Niphargus (exceptionally coexisting with it) in two small disjunct areas on both edges of the Pyrenees (Pretus and Sabater, 1990; Notenboom, 1991; Karaman, 2015a; b).

Karaman and Ruffo (1986) suggested that the diversification of the family began in the basins of the Para- tethys Sea during the Tertiary Period, from which European fresh waters were subsequently colonised. But the discovery of casts of niphargids in Late Eocene Baltic amber (ca. 45-50 Myr old; Coleman and Myers, 2001; Coleman and Ruffo, 2002; Jażdżewski and Kupryjanowicz, 2010) rules out this hypothesis since the birth of Parathethys as an enclosed basin with reduced salinity and endemic faunas took place only afterwards, at the early Oligocene at most (Rögl, 1997). McInerney et al. (2014) have attributed a much older, late Cretaceous age to the family, and an origin in NW Europe rather than in the Balkan area followed by a gradual range expansion across central Europe to reach its current distribution range. A third, alternative scenario where niphargids colonized freshwaters directly from the sea multiple times independently during their evolutionary history, and where the lineage of Haploginglymus settled in Iberia when it was an island during the late Cretaceous is not favored here since, if this were the case: (1) it is hardly conceivable that Niphargus was not established throughout the entire Peninsula when it is present in French territories adjacent to the Atlantic and the Mediterranean, and vice-versa, that Haploginglymus is not present in France; (2) there are no niphargids on North Atlantic oceanic islands, nor on Mediterranean islands such as the Balearics, discon- 
Table 4. Uncorrected pairwise cox 1 distances (p-distance) among Haploginglymus taxa.

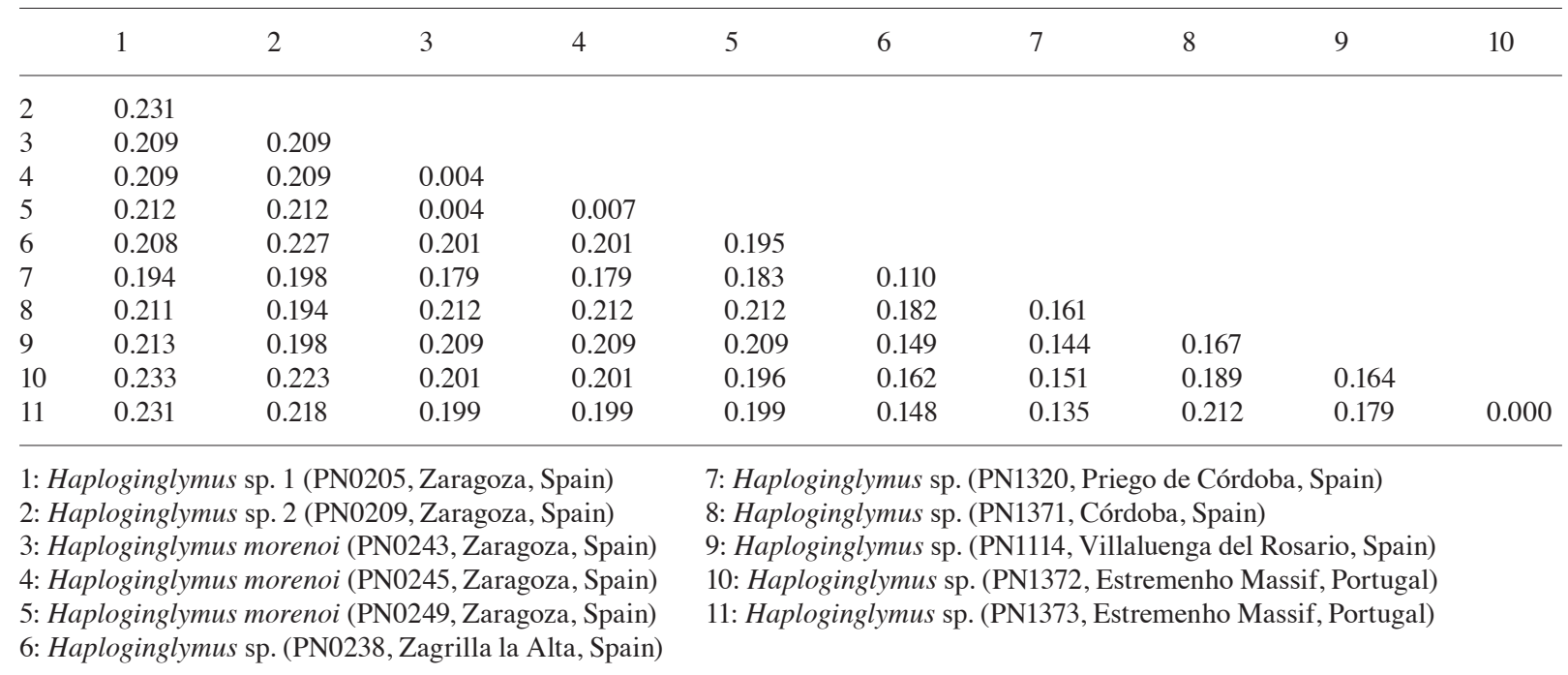

nected from the continents at least since the end of the Oligocene, but where ulterior marine transgressive pulses have constrained severely the extension of emerged land; (3) the distribution of the family is not limited to areas covered by epicontinental seas in the geological past (Notenboom, 1991); and (4) brackish water species are exceptional among members of the family (Notenboom, 1991).

Our study reveals a strongly supported sister relationship between niphargids and pseudoniphargids that deserves a comment since it is relevant for the origin and biogeography of the Niphargidae. Contrary to niphargids, which are mainly limnic and are present on territories not formerly occupied by the sea, the Pseudoniphargidae are undeniably thalassoid, being present even on oceanic islands that have never been connected to the continents (Bermuda, Canaries, Madeira, Azores; Stock et al., 1986; Stock, 1988; Stock and Abreu, 1992; Stock, 1980). The study of the phylogenetic relationships among members of the family based on both morphological (Notenboom, 1988) and molecular features (analyses currently under way in our lab) has lead to the identification of a monophyletic cluster of species of Pseudoniphargus Chevreux, 1901 cantoned on the western edge of the Pyrennees - Basque Country, bordering the Gulf of Biscay - as the most primitive lineage within the family. Remarkably, the most primitive niphargids are also found in an area adjacent to the Gulf of Biscay (Great Britain; Mcinerney et al., 2014). Accordingly, we suggest that niphargids - contrary to pseudoniphargids have colonized continental waters only once, and from a marine ancestor common to both families, and that this common ancestor most probably lived on the NE Atlantic coasts at the end of the Cretaceous. Once established in continental waters, niphargids proceeded to spread across Europe, with the colonisation of Iberia by the ancestor of Haploginglymus taking place before the rise of the Pyrenees 55-47 Myr ago. Niphargids should continue to be considered as a primary limnic group for biogeographic purposes, despite its presumed relatively recent (late Cretaceous) marine origin and sister relationship with the (thalassoid) Pseudoniphargidae.

\section{Acknowledgements}

We thank Ana Sofía Reboleira (Aveiro), Antonio Moreno de la Rosa and Manuel Baena (Córdoba) for the provision of the Haploginglymus material from Estremenho Massif, Zagrilla la Alta and Córdoba City used in the analyses, respectively, and Ignacio Ribera (Barcelona) for the Niphargus from Usabeiartza peatbog (Andoain). Marta Gutiérrez (Cantabria), Toni Pérez Fernández (Villacarrillo) and Pedro Oromí (Tenerife) sent us part of the specimens of Pseudoniphargus used as outgroups. Alberto Tinaut, Virginia Salabert and $\mathrm{M}^{\mathrm{a}}$ Dolores Lara (Granada) kindly offered us their material of the new species for study. Furthermore we wish to thank the two reviewers, Denis Copilas-Ciocianu (Charles University, Prague) and Cene Fišer (University of Ljubljana) for their constructive comments. This is a contribution to research project CAREQ authorised by Consejería de Cultura of Junta de Andalucía and to project CGL2016-76164-P (AEI/FEDER, UE), financed by the Spanish State Research Agency (Agencia Española de Investigación, AEI) and the European Regional Development Fund (Fondo Europeo de Desarrollo Regional, FEDER). 


\section{References}

Camacho AI. 2005. Expanding the taxonomic conundrum: Three new species of groundwater crustacean (Syncarida, Bathynellacea, Parabathynellidae) endemic to the Iberian Peninsula. Journal of Natural History 39: 1819-1838.

Coleman HO, Myers AA. 2001. New Amphipoda from Baltic amber. Polskie Archiwum Hydrobiologii 47: 457-464.

Coleman CO, Ruffo S. 2002. Another discovery of a niphargid amphipod (Crustacea) in Baltic amber. Mitteilungen des Geologischen-Palaontologischen Instituts, Universitat Hamburg 86: 239-244.

Colgan DJ, McLauchlan A, Wilson GDF, Livingston SP, Edgecombe GD, Macaranas J, Cassis G, Gray MR. 1998. Histone H3 and U2 snRNA DNA sequences and arthropod molecular evolution. Australian Journal of Zoology 46: 419.

Esmaeili-Rineh S, Sari A, Delić T, Moškrič A, Fišer C. 2015. Molecular phylogeny of the subterranean genus Niphargus (Crustacea: Amphipoda) in the Middle East: A comparison with European Niphargids. Zoological Journal of the Linnean Society 175: 812-826.

Fišer C, Sket B, Trontelj P. 2008. A phylogenetic perspective on 160 years of troubled taxonomy of Niphargus (Crustacea: Amphipoda). Zoologica Scripta 37: 665-680.

Folmer O, Black M, Hoeh W, Lutz R, Vrijenhoek R. 1994. DNA primers for amplification of mitochondrial cytochrome $\mathrm{C}$ oxidase subunit I from diverse metazoan invertebrates. Molecular Marine Biology and Biotechnology 3: 294-299.

Hekmatara M, Zakšek V, Heidari Baladehi M, Fišer C. 2013. Two new species of Niphargus (Crustacea: Amphipoda) from Iran. Journal of Natural History 47: 1421-1449.

Horton T, Lowry JK. 2013. Niphargidae Bousfield, 1977. In: Horton T, Lowry J, De Broyer C, Bellan-Santini D, Coleman CO, Daneliya M, Dauvin J-C, Fišer C, Gasca R, Grabowski M, Guerra-García JM, Hendrycks E, Holsinger J, Hughes L, Jaume D, Jazdzewski K, Just J, Kamaltynov RM, Kim Y-H, King R, Krapp-Schickel T, LeC ZW, ed. World Amphipoda Database at http://www.marinespecies.org/aphia.php? $p=$ taxdetails\&id=545660.

Iannilli V, Minelli A, Ruffo S. 2009. Hapoginglymus morenoi (Crustacea, Amphipoda, Niphargidae) a new intersticial Iberian species with unusual maxilliped. Bollettino del Museo Civico di Storia Naturale di Verona Botanica Zoologia 33: 105-112.

Jażdżewski K, Kupryjanowicz J. 2010. One more fossil niphargid (Malacostraca: Amphipoda) from Baltic amber. Journal of Crustacean Biology 30: 413-416.

Karaman GS. 1986. Description of Haploginglymus mateusi, new species of subterranean Gammaridea from Iberian Peninsula with remarks to other taxa of this genus (Fam. Nipharguidae). Poljepriveda $i$ šumarstvo 32: 75-90.

Karaman GS. 2015a. Two new members of the family Niphargidae (Gammaridea) from Spain (Contribution to the Knowledge of the Amphipoda 281). Biologia Serbica 37: 3-21.

Karaman GS. 2015b. New data on two subterranean species of the family Niphargidae from Spain, Niphargus gallicus Schell., 1935 and N. delamarei Ruffo, 1954. Contributions. Section of Natural, Mathematical \& Biotechnical Sciences 36: 105-120.

Karaman GS, Ruffo S. 1986. Amphipoda: Niphargus-group (Niphargidae sensu Bousfield, 1982). In: Botosaneanu L, ed.
Stygofauna Mundi: A faunistic, distributional and ecological synthesis of the world fauna inhabiting subterranean waters (including the marine interstitial). Leiden: EJ Brill Leiden, The Netherlands, 514-534.

Katoh K, Standley DM. 2013. MAFFT multiple sequence alignment software version 7: Improvements in performance and usability. Molecular Biology and Evolution 30: 772-780.

Kumar S, Stecher G, Tamura K. 2016. MEGA7: Molecular Evolutionary Genetics Analysis version 7.0 for bigger datasets. Molecular Biology and Evolution 33: 1870-1874.

Lanfear R, Calcott B, Ho SYW, Guindon S. 2012. Partitionfinder: combined selection of partitioning schemes and substitution models for phylogenetic analyses. Molecular Biology and Evolution 29: 1695-701.

Lowry, J. 2010. Niphargus Schiödte, 1849. In: Horton T, Lowry J, De Broyer C, Bellan-Santini D, Coleman CO, Daneliya M, Dauvin J-C, Fišer C, Gasca R, Grabowski M, Guerra-García JM, Hendrycks E, Holsinger J, Hughes L, Jaume D, Jazdzewski K, Just J, Kamaltynov RM, Kim Y-H, King R, KrappSchickel T, LeCroy S, Lörz A-N, Senna AR, Serejo C, Sket B, Tandberg AH, Thomas J, Thurston M, Vader W, Väinölä R, Vonk R, White K, Zeidler W. 2017. World Amphipoda Database. Accessed through: World Register of Marine Species at http://www.marinespecies.org/aphia.php?p=taxdetails\&id $=545672$ on $2017-04-10$

Lowry JK, Myers AA. 2013. A Phylogeny and Classification of the Senticaudata subord. nov. (Crustacea: Amphipoda). Zootaxa 3610: 1-80.

Mateus A de M, Oliveira-Mateus E. 1958. Un nouveau genre et une nouvelle espèce d’Amphipode troglobie du Portugal. Publicaçoes do Instituto de Zoologia 'Dr. Augusto Nobre' 59: 5-15.

McInerney CE, Maurice L, Robertson AL, Knight LRFD, Arnscheidt J, Venditti C, Dooley JSG, Mathers T, Matthijs S, Eriksson K, Proudlove GS, Hänfling B. 2014. The ancient Britons: Groundwater fauna survived extreme climate change over tens of millions of years across NW Europe. Molecular Ecology 23: 1153-1166.

Meleg IN, Zakšek V, Fišer C, Kelemen BS, Moldovan OT. 2013. Can Environment Predict Cryptic Diversity? The Case of Niphargus Inhabiting Western Carpathian Groundwater (D Russo, Ed.). PLoS ONE 8: e76760.

Nguyen LT, Schmidt HA, von Haeseler A, Minh BQ. 2015. IQTREE: a fast and effective stochastic algorithm for estimating maximum-likelihood phylogenies. Molecular biology and evolution 32: 268-74.

Notenboom J. 1988. Phylogenetic relationships and biogeography of the groundwater-dwelling amphipod genus Pseudoniphargus (Crustacea), with emphasis on the Iberian species. Bijdragen tot de Dierkunde 58: 159-204.

Notenboom J. 1990. Introduction to Iberian groundwater amphipods. Limnetica 6: 165-176.

Notenboom J. 1991. Marine regressions and the evolution of groundwater dwelling amphipods (Crustacea). Journal of Biogeography: 437-454.

Pretus JL, Sabater F. 1990. A new Haploginglymus (Crustacea: Amphipoda) coexisting with Niphargus sp. in a spring south of Pyrenees (Catalonia, N.E. Spain). Stygologia 5: 143-152.

Rambaut A, Suchard MA, Drummond AJ. 2013. Tracer v1. 6. http://tree.bio.ed.ac.uk/software/tracer/

Rögl F. 1997. Palaeogeographic considerations for Mediterranean and Paratethys seaways (Oligocene to Miocene). Annalen des 
Naturhistorischen Museums in Wien. Serie A für Mineralogie und Petrographie, Geologie und Paläontologie, Anthropologie und Prähistorie: 279-310.

Ronquist F, Teslenko M, Van Der Mark P, Ayres DL, Darling A, Höhna S, Larget B, Liu L, Suchard MA, Huelsenbeck JP. 2012. Mrbayes 3.2: Efficient bayesian phylogenetic inference and model choice across a large model space. Systematic Biology 61: 539-542.

Sket B. 1971. Vier Neue Aberrante Niphargus-Arten (Amphipoda, Gammaridae) und Einige Bemerkungen zur Taxonomie der Niphargus-ähnlichen Gruppen. Razprave SAZU, Dissertationes Academia Scientiarum et Artium Slovenica, Classis IV: Historia Naturalis et Medicina 14: 1-25.

Sket B. 1981. Niphargobates orophobata n. g., n. sp. (Amphipoda, Gammaridae, s. 1.) from cave waters in Slovenia (NW Yugoslavia). Biološki vestnik 29: 105-118.

Stock JH. 1980. Dècouverte, dans le nord-ouest de l'espagne, d'une deuxiéme espéce d'Haploginglymus, genre de crustacés amphipodes hypogés endémique de la Peninsule Ibérique. Bulletin Zoologisch Museum, Universiteit van Amsterdam 7: 141-147.

Stock JH. 1988. The amphipod genus Pseudoniphargus (Crustacea) in the Canary Islands. Bijdragen tot de Dierkunde 58: 47-78.

Stock JH, Abreu AD. 1992. Three new species of Pseudoniphargus (Crustacea: Amphipoda) from the Madeira archipelago. Boletim do Museu Municipal do Funchal 44: 131-155.

Stock JH, Holsinger JR, Sket B, Iliffe TM. 1986. Two new species of Pseudoniphargus (Amphipoda) in Bermudian groundwaters. Zoologica Scripta 15: 237-249.

Švara V, Delić T, Rađa T, Fišer C. 2015. Molecular phylogeny of Niphargus boskovici (Crustacea: Amphipoda) reveals a new species from epikarst. Zootaxa 3994: 354-376.
Talavera G, Castresana J. 2007. Improvement of phylogenies after removing divergent and ambiguously aligned blocks from protein sequence alignments. Systematic Biology 56: 564-577.

Trontelj P, Douady CJ, Fišer C, Gibert J, Gorički Š, Lefébure T, Sket B, Zakšek V. 2009. A molecular test for cryptic diversity in ground water: How large are the ranges of macrostygobionts? Freshwater Biology 54: 727-744.

Vergés J, Fernàndez M, Martínez A. 2002. The Pyrenean orogen: pre-, syn-, and post-collisional evolution. Journal of the Virtual Explorer 8: 57-76.

Verovnik R, Sket B, Trontelj P. 2005. The colonization of Europe by the freshwater crustacean Asellus aquaticus (Crustacea: Isopoda) proceeded from ancient refugia and was directed by habitat connectivity. Molecular Ecology 14: 4355-4369.

Xia X. 2013. DAMBE5: a comprehensive software package for data analysis in molecular biology and evolution. Molecular Biology and Evolution 30: 1720-8.

Xia X, Xie Z, Salemi M, Chen L, Wang Y. 2003. An index of substitution saturation and its application. Molecular Phylogenetics and Evolution 26: 1-7.

Zakšek V, Sket B, Trontelj P. 2007. Phylogeny of the cave shrimp Troglocaris: Evidence of a young connection between Balkans and Caucasus. Molecular Phylogenetics and Evolution 42: 223-235.

Received: 20 February 2017

Revised and accepted: 23 May 2017

Published online: 23 October 2017

Editor: R. Vonk 


\section{Online Supplementary Information}

S1. List of all taxa included in the analyses with their respective geographical origin, voucher ID and GenBank accession codes.

S2. Maximum likelihood phylogenetic tree based on the analysis of the cox 1 alignment. Node numbers represent statistical bootstrap support (only values $\geq 70$ are shown). Tip labels refer to the species names and their respective GenBank accession codes.

S3. Maximum likelihood phylogenetic tree based on the analysis of the H3 alignment. Node numbers represent statistical bootstrap support (only values $\geq 70$ are shown). Tip labels refer to the species names and their respective GenBank accession codes.

S4. Maximum likelihood phylogenetic tree based on the analysis of the LSU alignment. Node numbers represent statistical bootstrap support (only values $\geq 70$ are shown). Tip labels refer to the species names and their respective GenBank accession codes.

S5. Maximum likelihood phylogenetic tree based on the combined analysis of cox1, H3 and LSU. Node numbers represent statistical bootstrap support (only values $\geq 70$ are shown).

S6. Bayesian phylogenetic tree based on the combined analysis of cox $1, \mathrm{H} 3$ and LSU. Node numbers represent posterior probabilities (only values $\geq 0.70$ are shown).

S7. Maximum likelihood phylogenetic tree based on the combined analysis of cox1 (excluding third coding positions), H3 and LSU. Node numbers represent statistical bootstrap support (only values $\geq 70$ are shown).

S8. Maximum likelihood phylogenetic tree based on the analysis of the reduced LSU alignment (ambiguosly aligned positions removed with Gblocks). Node numbers represent statistical bootstrap support (only values $\geq 70$ are shown). 


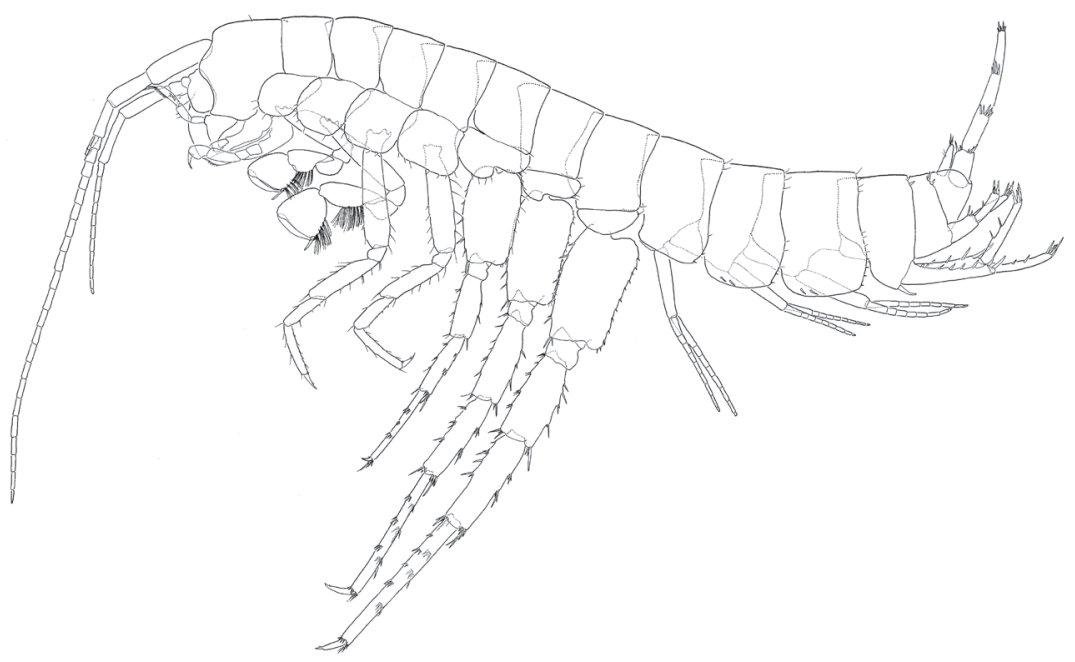

Fig. 4. Haploginglymus geos sp. nov., brooding female general aspect.

\section{Appendix}

\section{Systematics}

Order Amphipoda Latreille, 1816

Family Niphargidae Bousfield, 1977

Genus Haploginglymus Mateus and Oliveira-Mateus, 1958

\section{Haploginglymus geos sp. nov. Jaume and Alvarez}

(Figs 4-13)

Material examined. Cueva del Ocho, Cazalla de la Sierra, Seville, Spain. Geos Spelaeological Society Catalogue ref. no.: CLS-12-Geos. Coordinates: (Datum WGS 84) N 38 2' 2.36"; W 5 5 54' 58.15"; 346 m above sea level.. Phreatic lake occupying bottom of cave. Holotype: female $7.5 \mathrm{~mm}$, preserved in single ethanol vial [RMNH.CRUS.A. 5072]. Paratypes: 9 females in single ethanol vial [RMNH.CRUS.A. 5073]. About 100 specimens in single ethanol vial deposited at IMEDEA. Collected by G. Alvarez and D. Jaume. Additional material examined: Cueva de Santiago Grande (CLS-2-Geos; cave placed adjacent to Cueva del Ocho). Numerous specimens. Collected by Alberto Tinaut, Virginia Salabert and $\mathrm{M}^{\mathrm{a}}$ Dolores Lara. Deposited at IMEDEA.

Diagnosis. Fourth and fifth peduncular segment of antenna about equal in length. Spines on basal endite (=outer lobe) of maxillule coarsely denticulate. Palp of maxilliped ordinary, unguiform, non-spatulate. Carpus of G1-G2 each longer than corresponding propodus. Basis of P5-P7 not expanded, slender, each with over- hanging posterodistal lobe. Telson cleft to only onethird of its total length.

Etymology. Species name refers to Geos Spelaeological Society (Seville), whose members explored for the first time the caves where the new species was discovered and collected the first specimens.

Distribution. Known only from phreatic subterranean waters of Cerro de Santiago (Cazalla de la Sierra, Seville; southern Spain). The area is connected hydrographically to the Guadalquivir River basin.

Description of brooding female. Body (Fig. 4) up to $7.6 \mathrm{~mm}$ long, anophthalmous, colourless. Head (Fig. $5 \mathrm{~A}$ ) rostrum absent; lateral lobes evenly rounded, slightly produced, each with submarginal row of short sensillae along dorsal margin; antennal sinus hardly excavated. Epimeral plates I-III (Fig. 12A) each with evenly rounded posterior margin and straight distal (= ventral) margin; posterodistal angle not produced, marked with tiny flagellate spine; armature (strong flagellate spines) of distal margin of plates as follows: plate I, naked; plate II, 1 or 2 spines; plate III, 2 or 3 spines. Urosomites I-III dorsolateral armature (Fig. 13A, C) consisting of one (urosomite I) or 2-3 (urosomite II) short, relatively slender spines at each side; urosomite III naked; urosomite I with one (exceptionally two on one side) stout curved strong ("ecdysial") spine implanted adjacent to insertion of U1, just in front of it (Fig. 13A).

Labrum (Fig. 6A) ordinary, globose. Paragnaths (Fig. 6B) with well-developed inner lobes.

Antennule (Fig. 5B) peduncle segments progressively shorter towards distal, relative lengths as 100: 73: 49; 


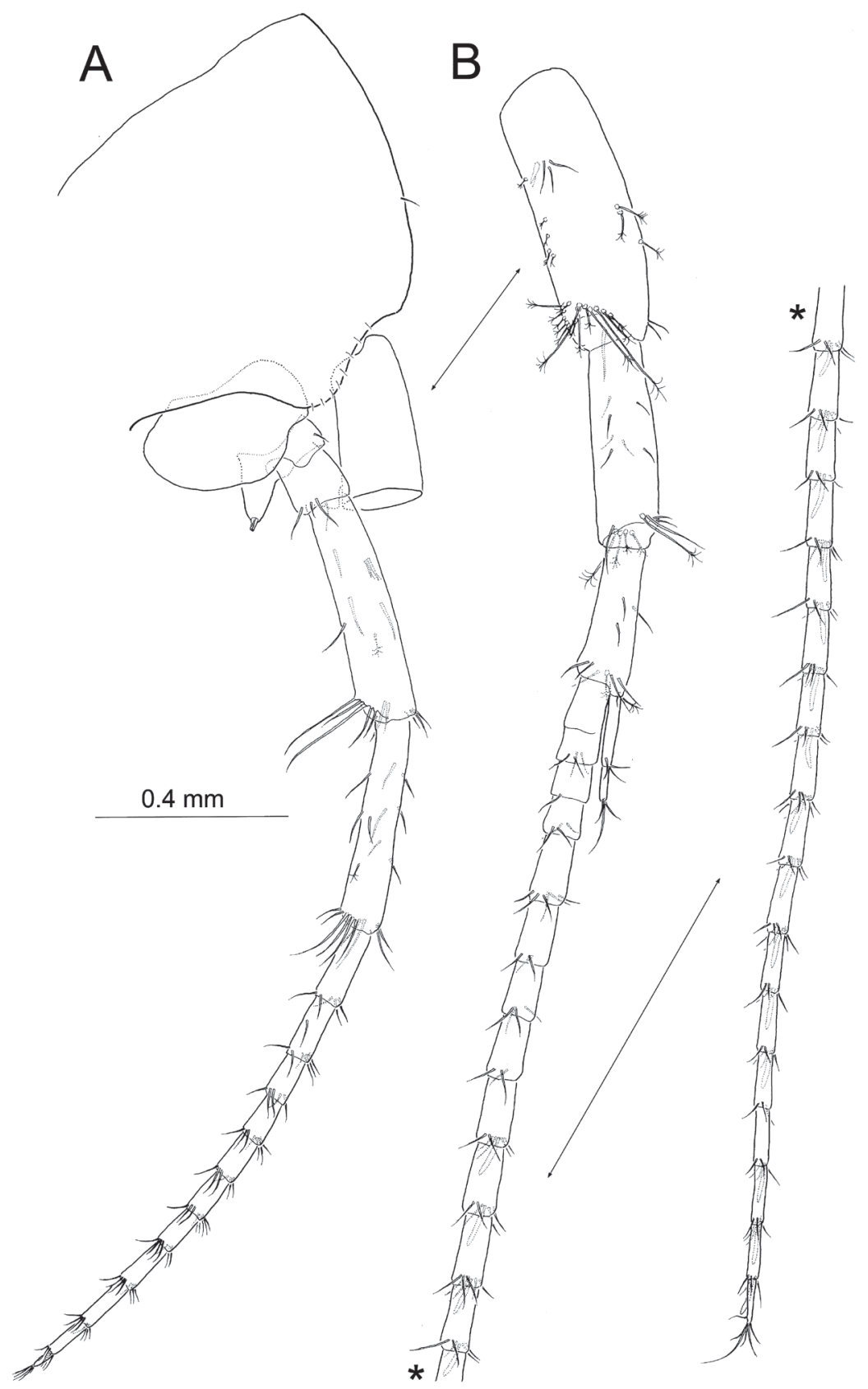

Fig. 5. Haploginglymus geos sp. nov., brooding female. A, inset of head with right $\mathrm{A} 2$ attached, lateral; $\mathrm{B}$, right $\mathrm{A} 1$, lateral. proximal segment provided with one (exceptionally two) short flagellate spines proximally on posteromedial surface. Main flagellum about 2.8 times longer than peduncle, distal articles each provided with short simple aesthetasc. Accessory flagellum 2-articulate, shorter than distal segment of peduncle.

Antenna (Fig. 5A) much shorter than antennule (at- taining only $49 \%$ length of A1). Proximal segment of 5-segmented peduncle swollen; gland cone on second segment slender; third segment with short triangular process protruding on distomedial margin; fourth and fifth segments relative length as $1: 0.96$, fourth segment with several spines on medial surface. Flagellum shorter than peduncle. 


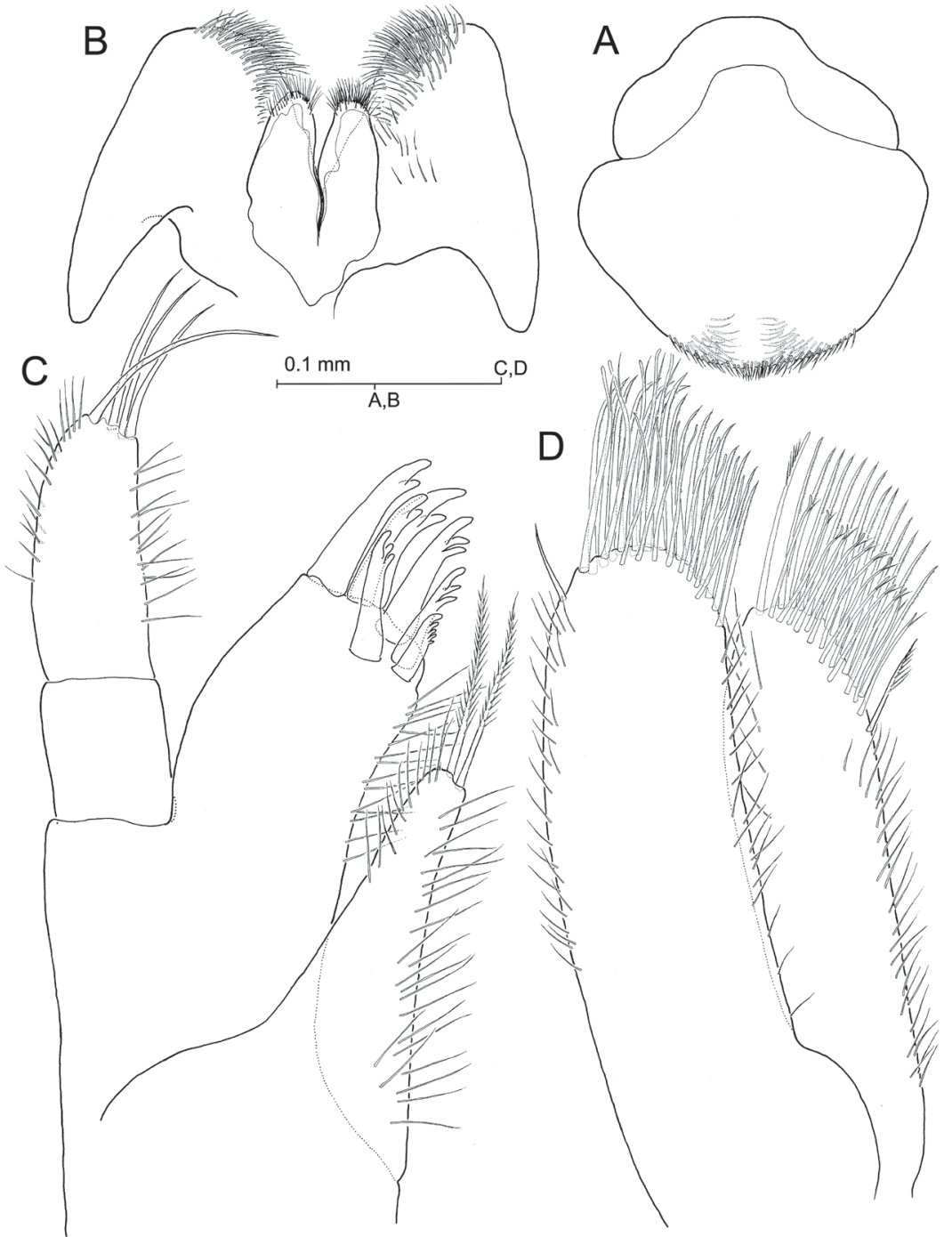

Fig. 6. Haploginglymus geos sp. nov., brooding female. A, labrum, anterior; B, paragnaths, dorsal; $\mathrm{C}$, left maxillule; D, left maxilla.
Left mandible (Fig. 7A) incisor 5-denticulate; lacinia 4-denticulate; spine row comprising 5-6 pappose elements plus three additional shorter ones disposed as collateral row as figured; molar columnar with short, reduced pappose molar seta. Palp 3-segmented, segments progressively longer towards distal; proximal segment naked; middle segment with two (exceptionally three) setae on ventral margin; distal segment with row of 9 to 15 setae along distal half of ventral margin, three longer terminal setae - one of which much stouter than rest -, and two setae (exceptionally one) implanted adjacent to each other proximally on outer surface of segment; anteromedial surface of third segment setulose (not shown in figure, but see
Fig. 8A, corresponding to right counterpart).

Right mandible (Figs 7B; 8A) incisor 4-denticulate; lacinia bifid, each branch 5- to 9-denticulate; spine row consisting of 4-5 elements plus shorter intercalary elements; molar seta much longer than left mandible counterpart.

Maxillules (Fig. 6C) symmetrical. Coxal endite (= inner plate) finger-like, crowned with two setae; basal endite (= outer plate) with seven stout spines, of which innermost shortest and 4- to 6-denticulate, adjacent spine 3-denticulate, next two spines 2- or 3-denticulate (one exceptionally 4-denticulate), and three outermost spines 2-denticulate. Endopod (= palp) 2-segmented, distal segment with 3-4 terminal setae. 


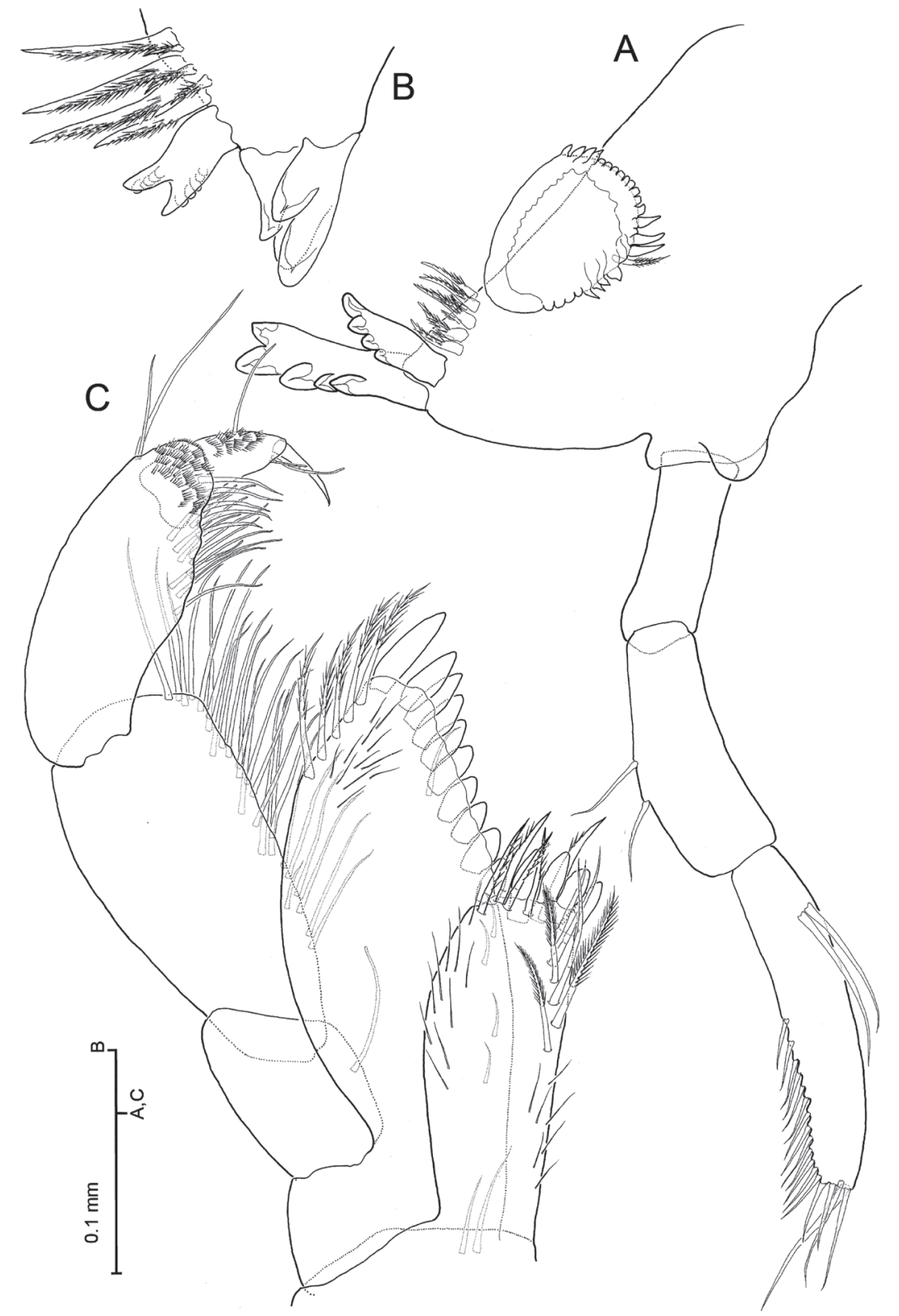

Fig. 7. Haploginglymus geos sp. nov., brooding female. A, left mandible, medial; $\mathrm{B}$, inset of distal margin of coxal gnathobase of right mandible, lateral; $\mathrm{C}$, left maxilliped, dorsal (= anterior).
Maxilla (Fig. 6D) ordinary, both endites subequal in length and with armature limited to distal margin; basal endite (= outer plate) with short simple seta implanted subdistally on outer margin, separated from terminal cluster of setae; coxal endite (= inner plate) devoid of oblique "facial" row of setae.

Maxilliped (Fig. 7C) basal endite (= inner plate) subrectangular, with 3-5 flattened, spatulate spines on distal margin; distal half of medial margin with submarginal row of pinnate setae. Ischial endite (= outer plate) rhomboidal, with row of 9-11 spatulate spines along distomedial margin and row of pinnate setae on distolateral margin. Other armature present on endites as figured. Palp (= merus-to-dactylus) ordinary; unguis present, slender, pointed, claw-like, attaining $77 \%$ length of dactylus.

Coxal gills (Figs 9A; 10A; 11A, C) present on G2 to P6, ordinary, sac-like, stalked. Oöstegites (Figs 9A; 11A) on G2 to P5, broad, with sparsely-set short simple setae on distal margin. 


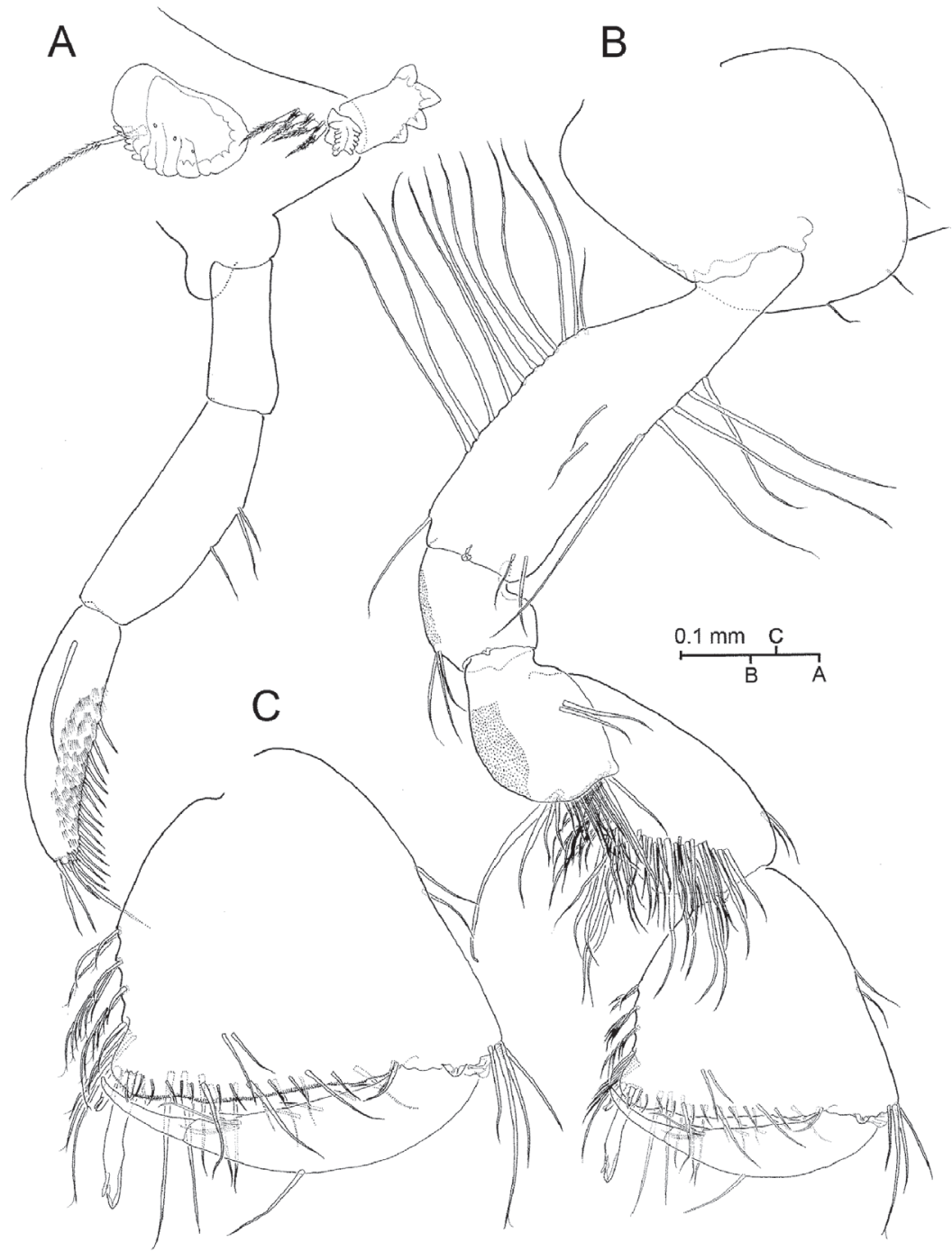

Fig. 8. Haploginglymus geos sp. nov., brooding female. A, right mandible; B, $\mathrm{G} 1$, medial; $\mathrm{C}$, inset of hand (= propodus + dactylus).
Gnathopod I (Fig. 8B) integument of posterior margin on ischium and merus micro-spinulate; merus with strong, long, bended posterodistal seta. Carpus elongate, slightly longer than propodus, provided with oblique patch of setae on medial surface and with five clusters of setae on posterior margin. Propodus (Fig. 8C) sub-chelate, trapezoidal, about as long as broad; palm angle with three flagellate spines disposed as figured (1 on medial side of margin; 2 on lateral side); longest spine very strong, attaining $35 \%$ length of propodus. Posterior margin of propodus with four clusters of setae. Dactylus with single seta on outer margin.

Gnathopod II (Fig. 9A) with integument on posterior margin of merus micro-spinulate. Carpus elongated, about 1.2 times longer than propodus, with well-delimited row (vs. patch on G1) of setae on medial surface; posterior margin with seven clusters of setae. Propodus (Fig. 9B) subsimilar but larger than G1 counterpart, posterior margin with six clusters of setae ( $v s .4$ on G1); large spine on palm angle attaining $33 \%$ length of propodus.

Pereiopod III (Fig. 10A) coxa subrectangular, about 1.2 times longer than broad. Nail (= dactylus+unguis) attaining $35 \%$ length of propodus; unguis $58 \%$ length of dactylus (Fig. 10B).

Pereiopod IV (Fig. 10C) shorter than P3 (92\% length of P3, excluding coxa); coxa subquadrate, slightly broader than long, with shallowly-excavated posterior margin. Nail attaining $36 \%$ length of propodus; unguis $63 \%$ length of dactylus (Fig. 10D). 


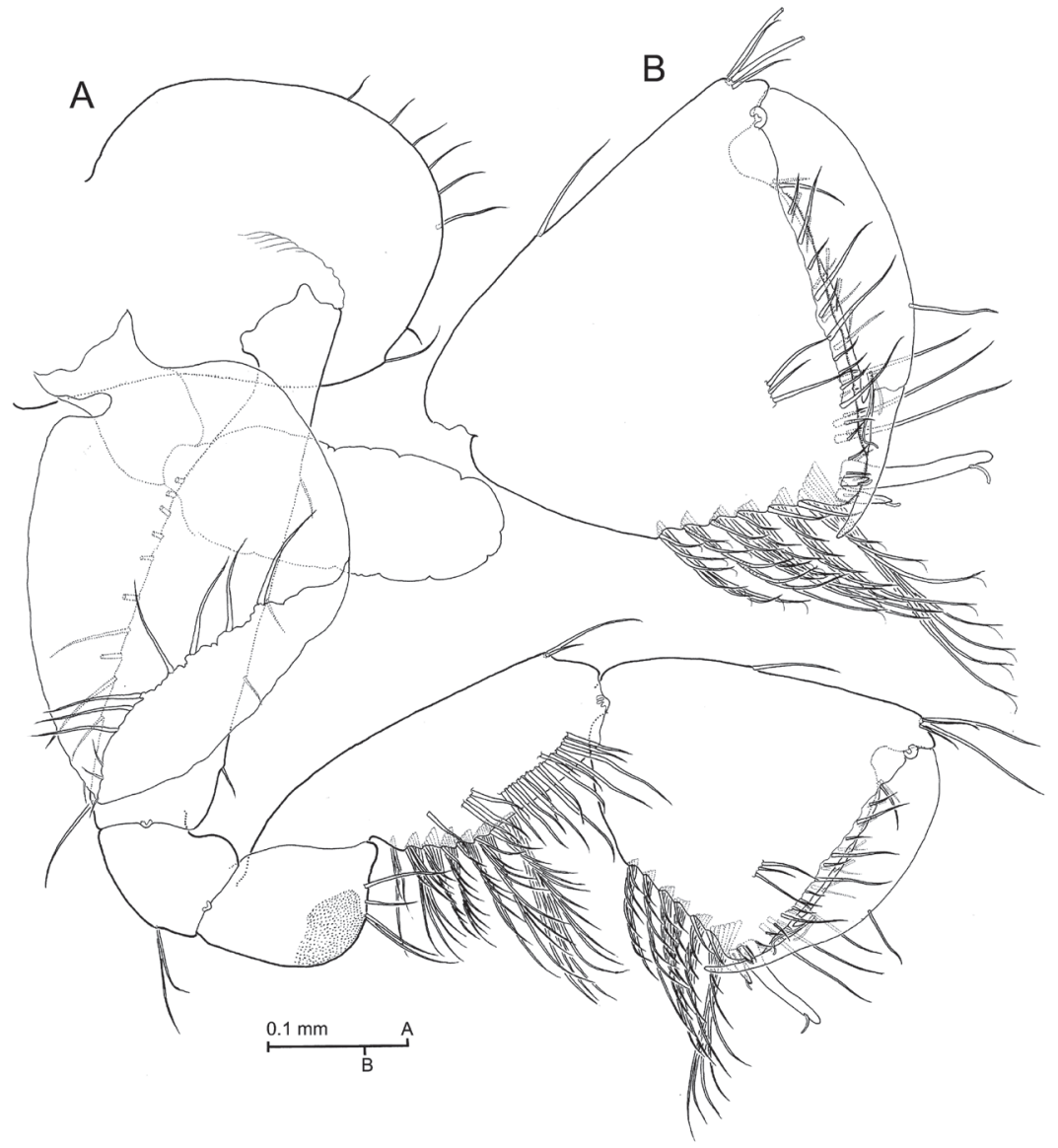

Fig. 9. Haploginglymus geos sp. nov., brooding female. A, G2 with oöstegite partially folded, medial; B, inset of hand (= propodus + dactylus).
Pereiopods V-VII progressively longer towards posterior, each with sub-rectangular basis showing welldeveloped posterodistal lobe. Pereiopod V (Fig. 11A) longer than P4; coxa with broad, overhanging anteroventral lobe. Basis 1.8 times as long as broad. Nail attaining $28 \%$ length of propodus; unguis $35 \%$ length of dactylus (Fig. 11B).

Pereiopod VI (Fig. 11C) coxa with distinct, evenly rounded anteroventral lobe. Basis twice as long as broad. Nail attaining $33 \%$ length of propodus; unguis $27 \%$ length of dactylus (Fig. 11D).

Pereiopod VII (Fig. 11E) basis 1.8 times as long as broad. Nail attaining $27 \%$ length of propodus; unguis $30 \%$ length of dactylus (Fig. 11F).

Pleopods I-III (Fig. 12B), ordinary, biramous, rami multi-articulate and longer than respective protopod; latter with pair of 5-denticulate retinacles. Exopod slightly shorter than endopod. Endopod with modified, bifid seta proximally on inner margin of proximal article; rest of setae plumose.
Uropod I (Fig. 13B) almost as long as U3. Protopod longer than rami, lacking basofacial spine; 1 terminal strong flagellate spine at each side; posterolateral margin with 5-7 shorter flagellate spines, and 2-4 similar spines along posteromedial margin. Exopod slightly shorter than endopod, with five (exceptionally 6 ) terminal spines; 1-2 spines along posterolateral margin and 0-1 spine on posteromedial margin. Endopod with five terminal spines; 2-3 spines along posteromedial margin; posterolateral margin of segment unarmed.

Uropod II (Fig. 13C, D) protopod with two terminal flagellate spines on posterolateral angle and single flagellate spine on posteromedial angle; posterolateral margin of segment with 1-2 flagellate spines; posteromedial margin unarmed. Rami unequal in length, with exopod much shorter than endopod. Exopod about same length as protopod, with five terminal spines and one spine (exceptionally none) about midway on each margin. Endopod with five terminal spines and other 2-3 along medial margin; lateral margin with 0-1 spine about midway. 


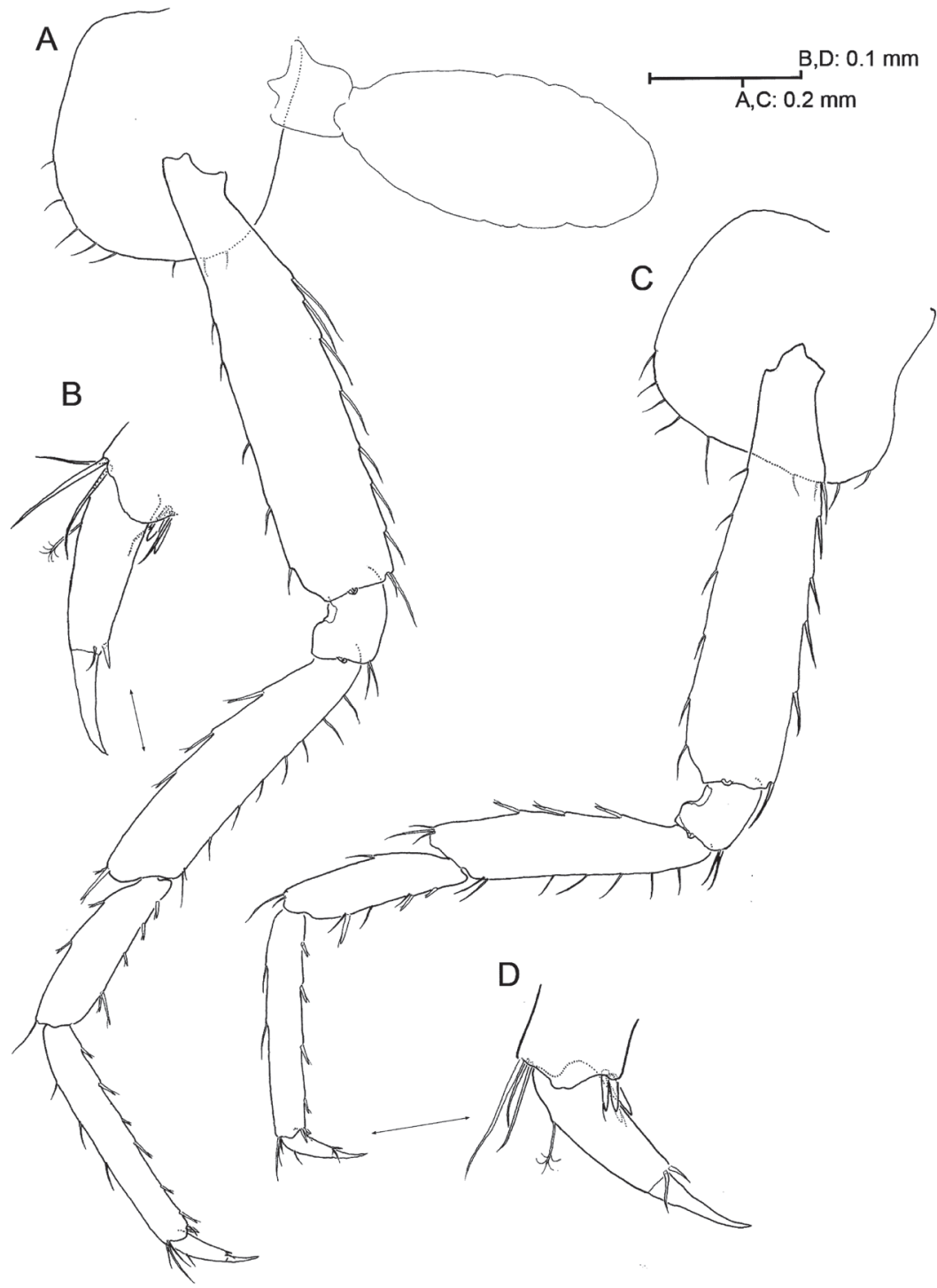

Fig. 10. Haploginglymus geos sp. nov., brooding female. A, right $\mathrm{P} 3$, medial (oöstegite omitted); B, inset of dactylus + unguis, medial; C, left P4, medial (coxal gill and oöstegite omitted); D, inset of dactylus + unguis, medial.
Uropod III (Fig. 13E) protopod about 1.5 times as long as broad, with 4-6 flagellate spines on distolateral angle and one short spine on distomedial angle; medial margin of segment with 0-2 short flagellate spines. Exopod about 6.4 times as long as broad, 3.7 times longer than protopod; armature consisting of 3-4 clusters of flagellate spines along lateral margin and 4-5 on medial margin distributed as figured. Endopod reduced, scalelike, with two (exceptionally 1 or 3 ) flagellate spines subdistally on medial margin.

Telson (Fig. 12C) slightly longer than broad, cleft to approx. one-third (34\%) of its maximum length. Armature consisting of 3-4 distal flagellate spines per lobe (exceptionally 5 on one lobe; see Fig. 12C); lateral margins unarmed except in exceptional specimens displaying one flagellate spine on one or both margins (as in Fig. 12C).

\section{Male}

Unknown.

Taxonomic remarks. Haploginglymus geos sp. nov. is the only member of the genus whose telson is cleft only to less than half of its total length (Table 5). Of the five formally described Haploginglymus species, only $H$. bergae Pretus and Sabater, 1990, and H. morenoi share 


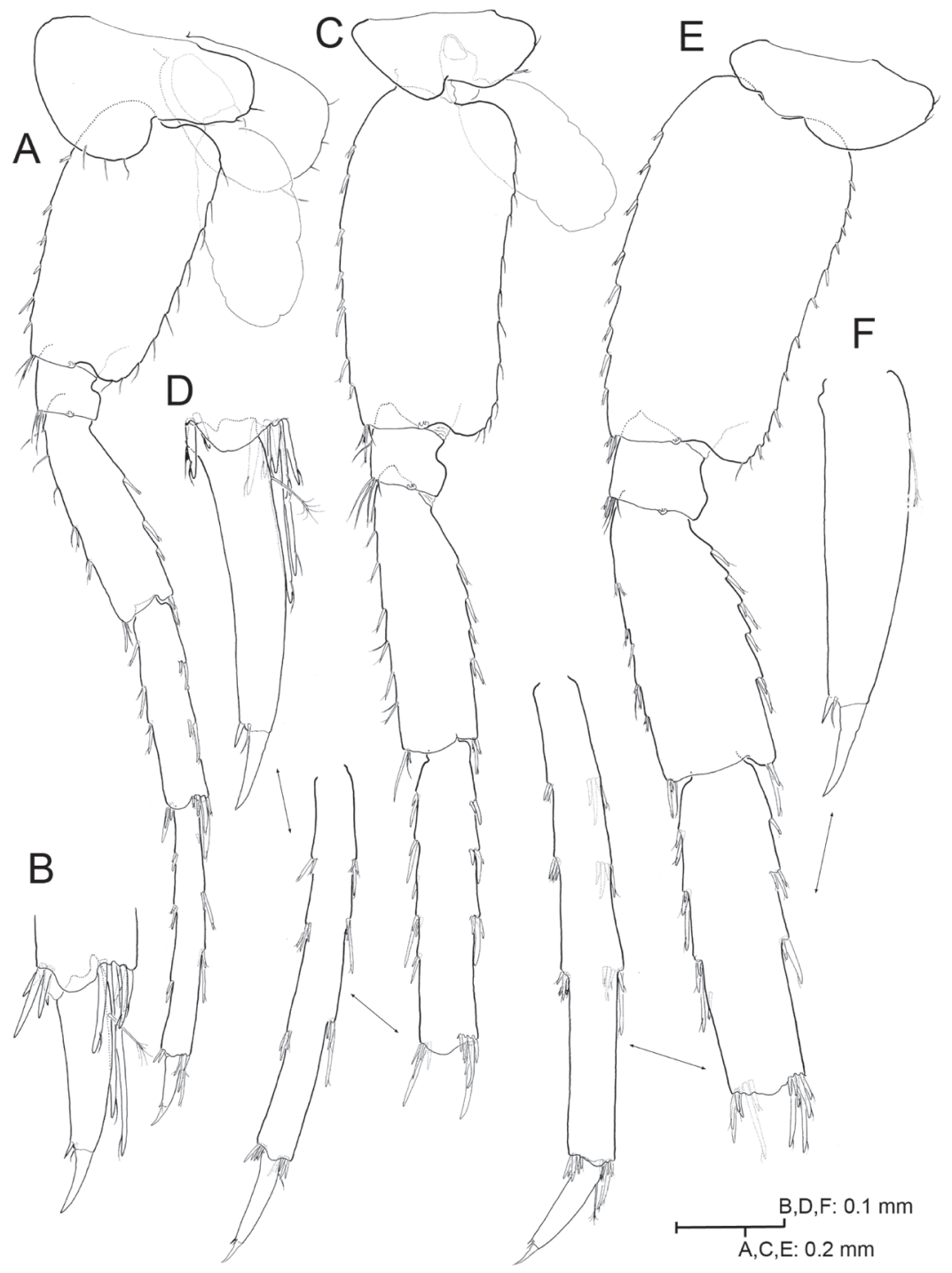

Fig. 11. Haploginglymus geos sp. nov., brooding female. A, left P5, lateral; B, inset of dactylus + unguis; C, left P6, lateral; D, inset of dactylus + unguis; E, left P7, lateral; F, inset of dactylus + unguis.

Table 5. Some features enabling distinction between Haploginglymus species.

\begin{tabular}{|c|c|c|c|c|c|c|}
\hline \multirow[t]{2}{*}{ Species } & \multicolumn{2}{|c|}{$\begin{array}{l}\text { Gnathopods, } \\
\text { (carpus/propodus) } \\
\text { length }\end{array}$} & \multirow[t]{2}{*}{$\begin{array}{l}\text { Maxillule, denticulation } \\
\text { of spines on basal endite }\end{array}$} & \multirow[t]{2}{*}{$\begin{array}{l}\text { Telson excavation } \\
\text { (vs. telson length) } \\
\text { length }\end{array}$} & \multirow[t]{2}{*}{$\begin{array}{l}\text { A2 peduncle, } \\
\text { (seg. 4/seg. 5) } \\
\text { lobe of basis }\end{array}$} & \multirow[t]{2}{*}{$\begin{array}{l}\text { P5-P7, } \\
\text { posterodistal }\end{array}$} \\
\hline & G1 & G2 & & & & \\
\hline H. bergae & 1.2 & 1.3 & fine; many denticles & $>50 \%$ & $45 \%$ & + \\
\hline H. bragai & 0.8 & $?$ & coarse; few denticles & $=50 \% ?$ & $51 \%$ & - \\
\hline H. lobatus & 0.8 & 1.1 & coarse; few denticles & $>50 \%$ & $47 \%$ & + \\
\hline H. mateusi & 0.8 & 0.9 & coarse; few denticles & $>50 \%$ & $51 \%$ & - \\
\hline H.morenoi & 1.4 & 1.3 & fine; many denticles & $>50 \%$ & $56 \%$ & - \\
\hline H. geos sp. nov. & $1.1-1.3$ & $1.2-1.3$ & coarse; few denticles & $<50 \%$ & $49 \%$ & + \\
\hline
\end{tabular}




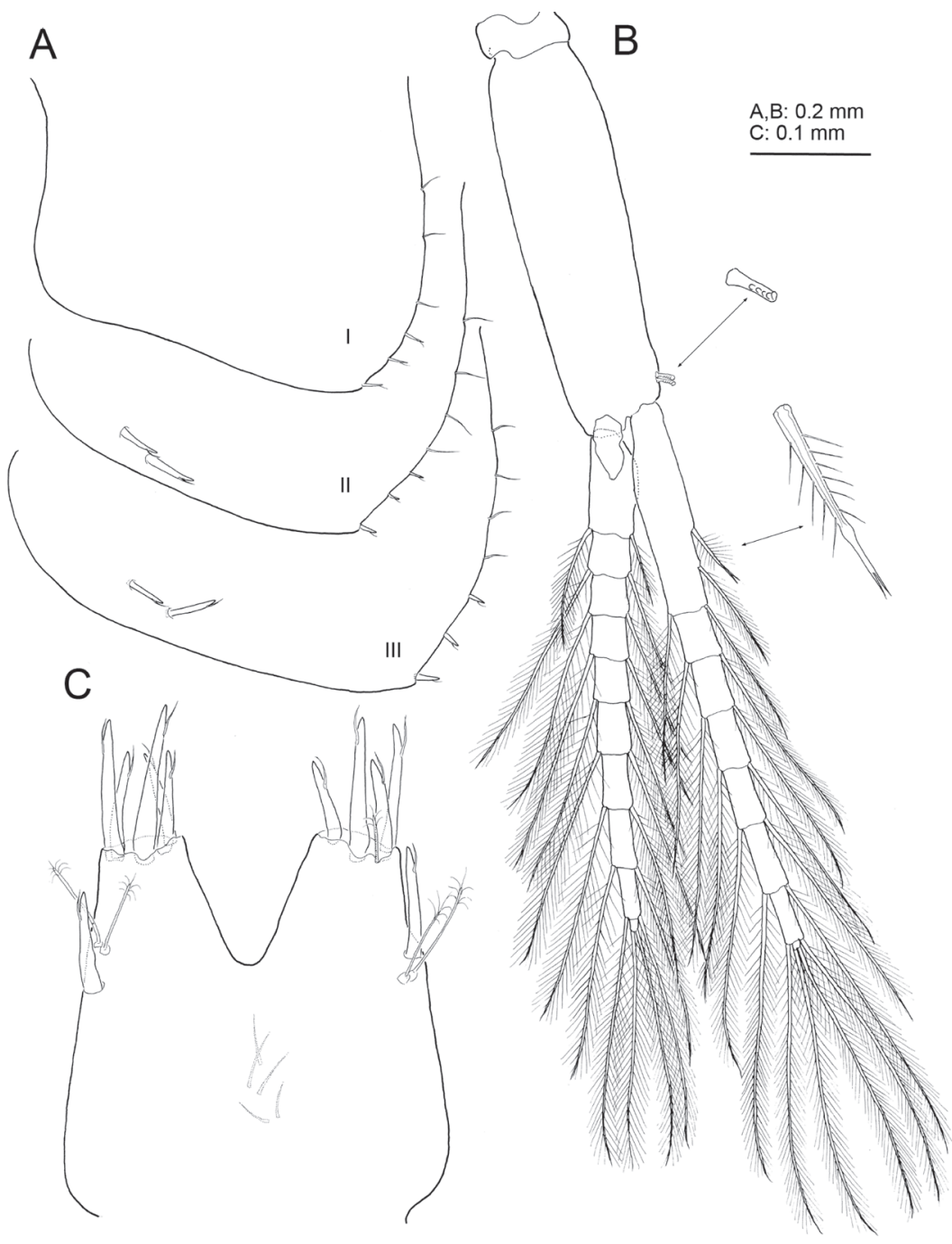

Fig. 12. Haploginglymus geos sp. nov., brooding female. A, left pleopod II, posterior; B, left epimeral plates I-III, lateral; C, telson, dorsal. with the new taxon the display of a G1 carpus that is longer than the corresponding propodus (Table 5). These species share also the relative elongation of carpus of G2 (Table 5). Whereas H. morenoi differs from the new species in the display of an aberrant, spatulate maxillipedal palp, an elongate, slender propodus in both gnathopods, and in the multi-denticulate condition of the spines of the basal endite (= outer plate) of maxillule, differences with $H$. bergae are subtler, but also consistent. Thus, the spines present on the basal endite of the maxillule aside the innermost one are multi-denticulate in $H$. bergae whereas only coarsely 2- or 3-denticulate at most in the new species; the epimeral plates are almost unarmed $v s$. armed in the new species; the telson is cleft to $60 \%$ of its length vs. only cleft to only $34 \%$ in the new species; the oöstegites are hypertrofied $v s$. of ordinary size in the new species; the U1 protopod displays a single spine on the posteromedial margin $v s .2-4$ spines in the new species; the outer margin of the U1 endopod bears one spine $v s$. none in the new species; and the distal segment of the mandibular palp displays only one proximolateral seta $v s$. two setae in the new species.

Additional relevant differences between the new taxon and the rest of Haploginglymus species are shown in Table 5. 


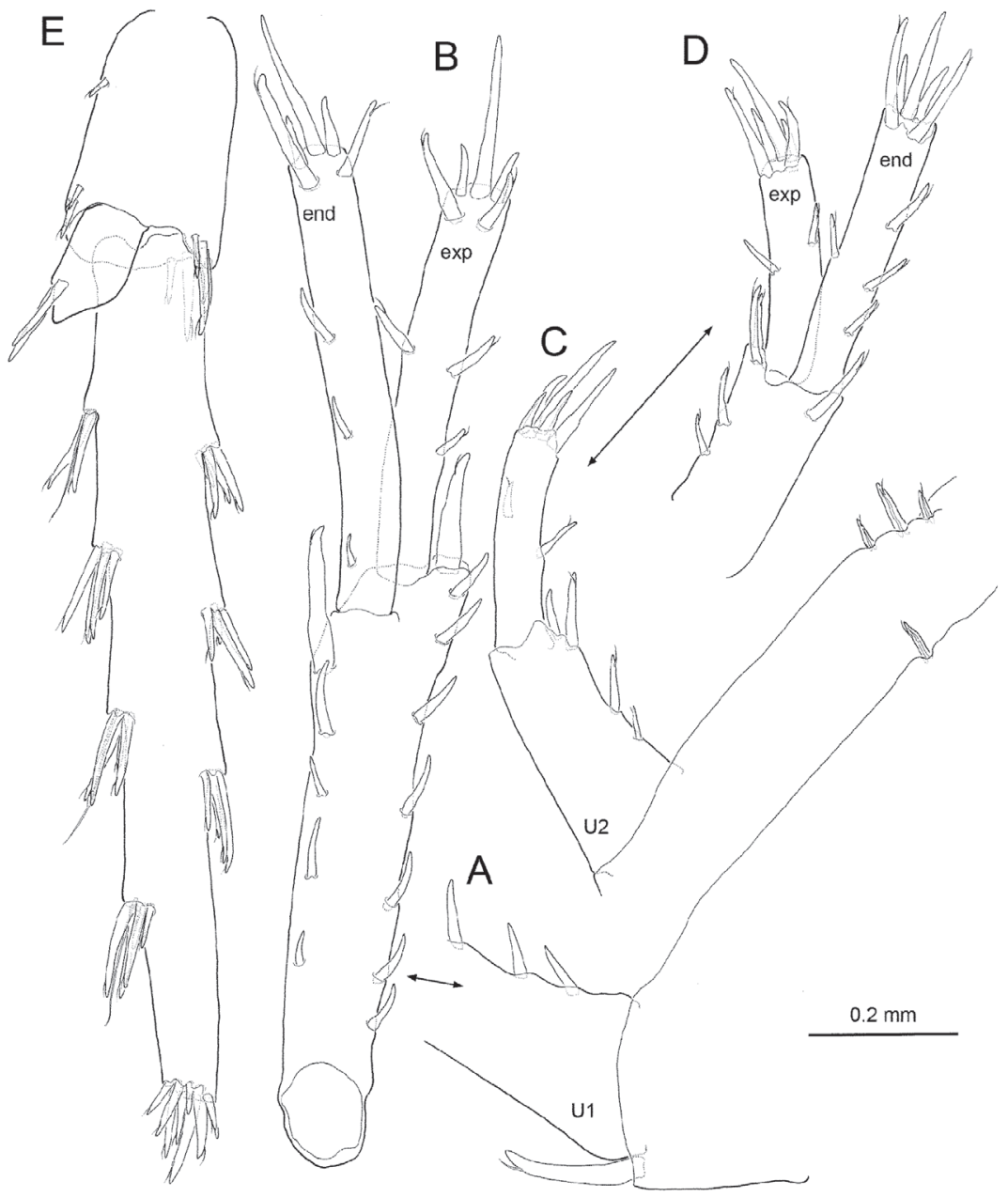

Fig. 13. Haploginglymus geos sp. nov., brooding female. A, first urosomite with proximal portion of right $\mathrm{U} 1$ attached, lateral; B, left U1, posterior; C, second urosomite with right $\mathrm{U} 2$ attached, lateral; $\mathrm{D}$, right $\mathrm{U} 2$, posterior; E, right $\mathrm{U} 3$, dorsal (= posterior). 